\title{
Aplikasi Asuhan Keperawatan Jiwa Pada Tn. A Dengan Masalah Gangguan Persepsi Sensori: Halusinasi Pendengaran
}

\author{
Desi Christ Natasha
}

desi.crist.natasya@gmail.com

\section{BAB 1}

PENDAHULUAN

\section{$1.1 \quad$ Latar Belakang}

Berbagai masalah kesehatan sering bermunculan karena kondisi kesehatan mental dan pikiran yang tidak terkendali. Masalah yang mengancam kesehatan jiwa salah satunya adalah Skizofrenia. Skizofrenia merupakan suatu kondisi gangguan psikotik yang ditandai dengan gangguan utama dalam pikiran, emosi dan perilaku yang terganggu, dimana berbagai pemikiran tidaksaling berhubungan secara logis, persepsi dan perhatian yang keliru (Makhruzah,Putri, \& Yanti, 2021). Skizofrenia merupakan gangguan mental berat dan kronis yang menyerang 20 juta orang di seluruh dunia (WHO, 2019).

Skizofrenia merupakan kelainan jiwa parah yang mengakibatkan stres tidak hanya bagi penderita juga bagi anggota keluarganya (Pardede, 2019). Skizofrenia merupakan sekumpulan sindroma klinik yang ditandai dengan perubahan kognitif, emosi, persepsi dan aspek lain dari perilaku. Skizofrenia adalah sekelompok reaksi psikotik yang memengaruhi berbagai area fungsi individu, termasuk berpikir, berkomunikasi, menerima, menginterpretasikan realitas, merasakan dan menunjukkan emosi. Menambahkan definisi skizofrenia yaitu penyakitkronis, parah, dan melumpuhkan, gangguan otak yang ditandai dengan pikiran kacau, waham, halusinasi, dan perilaku aneh (Pardede, Keliat,\& Yulia, 2015). Gejala skizofrenia dapat mengalami perubahan semakin membaik atau semakin memburuk dalam kurun waktu tertentu, hal tersebut berdampak dengan hubungan pasien dengan diirnya sendiri serta orang yang dekat dengan penderita (Pardede, Keliat \& Wardani, 2013). Faktor-faktor yang mempengaruhi kekambuhan penderita skizofrenia dengan halusinasi meliputi ekspresi emosi keluarga yang tertinggi, pengetahuan keluarga yang kurang, ketersediaan pelayanan kesehatan, penghasilan keluarga dan kepatuhan minum obat pasien skizofrenia (Afconneri, 2020). 
Skizofrenia merupakan salah satu gangguan jiwa dengan gejala positif yang sering muncul yaitu halusinasi. Pasien dengan diagnosis medis skizofrenia sebanyak $70 \%$ mengalami halusinasi. Halusinasi merupakan salah satu masalah keperawatan yang dapat ditemukan pada pasien gangguan jiwa. Sebagian besar pasien halusinasi mengalami sensasi berupa suara, penglihatan, pengecapan, perabaan, atau penghiduan tanpa stimulus yang nyata (Keliat dkk, 2015). Halusinasi merupakan keadaan seseorang mengalami perubahan dalam pola dan jumlah stimulasi yang diprakarsai secara internal atau eksternal disekitar dengan pengurangan, berlebihan, distorsi, atau kelainan berespon terhadap setiap stimulus (Pardede, Keliat,\& Yulia, 2015). Orang yang mengalami halusinasi disebabkan karena ketidakmampuan pasien dalam menghadapi stressor. Orang dengan halusinasi kurang memiliki kemampuan dalam mengontrol pikirannya. Biasanya orang dengan halusinasi tidak dapat membedakan antara stimulus yang nyata dan stimulus yang palsu (Yosep, 2017).

Tanda dan gejala yang muncul pada pasien halusinasi meliputi sering mendengar suara orang bicara tanpa ada orangnya, melihat benda, orang, atau sinar tanpa ada objeknya, menghidu bau-bauan yang tidak sedap, seperti bau badan padahal tidak, merasakan pengecapan yang tidak enak, dan merasakan rabaan atau gerakan badan. Selain itu, tanda dan gejala halusinasi yang sering muncul lainnya meliputi sulit tidur, khawatir, serta takut, berbicara sendiri, tertawa sendiri, curiga, mengarahkan telinganya ke arah tertentu, tidak dapat memfokuskan pikiran, konsentrasi buruk, melamun dan menyendiri. Kemudian pasien dengan halusinasi juga memiliki tanda dan gejala seperti melihat ke satu arah, diam sambil menikmati halusinasinya, disorientasi tempat, waktu, orang, atau situasi, afek datar, mondar-mandir, dan juga kurang mampu merawat diri (Keliat, 2020). Halusinasi jika tidak segera dikenali dan diobati, akan muncul pada pasien dengan keluhan kelemahan, histeria, ketidakmampuan mencapai tujuan, pikiran buruk, ketakutan berlebihan, dan tindakan kekerasan. Diperlukan pendekatan dan manajemen yang baik untuk meminimalkan dampak dan komplikasi halusinasi (Akbar \& Rahayu, 2021)

Survey awal pada pembuatan asuhan keperawatan ini dilakukan di Rsj. Prof. Dr. Muhammad Ildrem diruangan sinabung dengan jumlah pasien 7 orang dengan masalah halusinasi tetapi yang menjadi subjek didalam pembuatan asuhan keperawatan ini adalah Tn.As umur 26 Tahun mengalami halusinasi pendengaran. Klien belum mampu mengontrol halusinasinya dan minum obat secara teratur. 


\subsection{Rumusan Masalah}

Berdasarkan masalah yang telah dipaparkan pada latar belakang maka rumusan masalah dalam askep ini yaitu Asuhan Keperawatan Halusinasi Pendengaran Tn.As di Rsj.Prof.Dr.Muhammad Ildrem

\subsection{Tujuan Penulisan}

\subsubsection{Tujuan Umum}

Mahasiswa mampu memberikan asuhan keperawatan jiwa pada Tn.As dengan

Halusinasi Pendengan di Rsj.Prof.Dr.Muhammad Ildrem

\subsubsection{Tujuan Khusus}

1. Mahasiswa mampu mengetahui defenisi, tanda dan gejala, faktor penyebab, mekanisme koping penatalaksanaan pada pasien dengan Halusinasi

2. Mahasiswa mampu melakukan pengkajian pada pasien dengan Halusinasi.

3. Mahasiswa mampu menegakkan diagnosa atau masalah keperawatan pada Tn.As dengan Halusinasi

4. Mahasiswa mampu menetapkan intervensi keperawatan pada diagnosa Halusinasi.

5. Mahasiswa mampu melakukan tindakan keperawatan Halusinasi

6. Mahasiswa mampu mengevaluasi sebagai tolak ukur guna menerapkan asuhan keperawatan dengan Halusinasi.

\subsection{Manfaat}

1. Responden

Diharapkan tindakan yang telah diajarkan dapat diterapkan secara mandiri untuk membantu dan mengontrol menghilangkan suara-suara yang didengar dan untuk mendukung kelangsungan kesehatan pasien.

2. Institusi pendidikan

Bagi institusi pendidikan diharapkan untuk menjadi acuan dalam melakukan kegiatan mahasiswa dalam bidang keperawatan jiwa 
3. Keluarga

Diharapkan keluarga dapat membantu dan acuan dalam menanganin anggota keluarga yang mengalami halusinasi. 


\section{BAB 2}

\section{TINJAUAN TEORITIS}

\subsection{Konsep Halusinasi}

\subsubsection{Defenisi}

Menurut Stuart, Keliat, dan Pasaribu (2016) halusinasi merupakan distrosi persepsi yang tidak nyata dan terjadi pada respons neurobiologis maladaptive. Halusinasi merupakan suatu penyerapan panca indera tanpa ada rangsangan dari luar, orang sehat persepsinya akurat,mampu mengidentifikasi dan menginter prestasikan stimulus berdasarkan informasi yang diterimanya melalui panca indera. Stimulus tersebut tidak ada pada pasien halusinasi. Akibat yang ditimbulkan pada pasien halusinasi dapat berakibat fatal karena beresiko tinggi untuk merugikan diri pasien sendiri, orang lain disekitarnya dan juga lingkungan.

Halusinasi adalah suatu keadaan dimana klien mengalami perubahan sensori persepsi yang disebabkan stimulus yang sebenarnya itu tidak ada (Herawati, 2020). Halusinasi pendengaran paling sering terjadi ketika klien mendengar suara suara, halusinasi ini sudah melebur dan pasien merasa sangat ketakutan, panik dan tidak bisa membedakan antara khayalan dan kenyataan yang dialaminya (Pardede, et al, 2021).

Dari defenisi di atas dapat disimpulkan bahwa halusinasi adalah hilangnya kemampuan manusia dalam membedakan rangsangan internal (pikiran) dan rangsangan eksternal (dunia luar), Klien memberi persepsi atau pendapat tentang lingkungan tanpa ada objek atau rangsangan yang nyata, sedangkan halusinasi pendengaran adalah persepsi atau tanggapan dari pancaidera (Mendengar) terhadap stimulus yang tidak nyata yang mempengaruhi perilaku individu.

\subsubsection{Proses Terjadinya Halusinasi}

Faktor predisposisi sebagai faktor risiko yang menjadi sumber terjadinya stres yang mempengaruhi tipe dan sumber dari individu untuk menghadapi stres baik yang biologis, psikososial dan sosial kultural. Membedakan stressor predisposisi menjadi tiga, meliputi biologis, psikologis dan sosial budaya. Stressor predisposisi ini kejadiannya telah berlalu (Stuart, 2015). Penjelasan secara rinci tentang ketiga stressor 
predisposisi tersebut sebagai berikut :

1. Faktor Predisposisi

a. Biologis

Faktor biologis terkait dengan adanya neuropatologi dan ketidakseimbangan dari neurotransmiternya. Dampak yang dapat dinilai sebagai manifestasi adanya gangguan adalah perilaku maladaptif klien. Secara biologis riset neurobiologikal memfokuskan pada tiga area otak yang dipercaya dapat melibatkan klien mengalami halusinasi yaitu sistem limbik, lobus frontalis dan hypothalamus (Wahyuni, 2015).

Pada klien dengan halusinasi diperkirakan mengalami kerusakan pada sistem limbic dan lobus frontal yang berperan dalam pengendalian atau pengontrolan perilaku, kerusakan pada hipotalamus yang berperan dalam pengaturan mood dan motivasi. Kondisi kerusakan ini mengakibatkan klien halusinasi tidak memiliki keinginan dan motivasi untuk berperilaku secara adaptif. Klien halusinasi juga diperkirakan mengalami perubahan pada fungsi neurotran smitter, perubahan dopamin, serotonin, norepineprin dan asetilkolin yang menyebabkan adanya perubahan regulasi gerak dan koordinasi, emosi, kemampuan memecahkan masalah; perilaku cende rung negatif atau berperilaku maladaptif; terjadi kelemahan serta penurunan atensi dan $\operatorname{mood}($ Zelika, 2015).

b. Faktor genetik

Genetik juga dapa memicu terjadi halusinasi pada seorang individu.Faktor genetik dapat berperan dalam respon sosial maladaptif. Terjadinya penyakit jiwa pada individu juga dipengaruhi oleh keluarganya dibanding dengan individu yang tidak mempunyai penyakit terkait. Banyak riset menunjukkan peningkatan risiko mengalami skizofrenia pada individu dengan riwayat genetik terdapat anggota keluarga dengan skizofrenia. Pada kembar dizigot risiko terjadi skizofrenia $15 \%$, kembar monozigot $50 \%$, anak dengan salah satu orang tua menderita skizofrenia berisiko $13 \%$, dan jika kedua orang tua mendererita skizofrenia berisiko 45\% (Pratiwi, 2018).

c. Psikologis

Meliputi konsep diri, intelektualitas, kepribadian, moralitas, pengalaman masa lalu, koping dan keterampilan komunikasi secara verbal . Konsep diri dimulai dari gambaran diri secara keseluruhan yang diterima secara positif atau negatif 
oleh seseorang. Penerimaan gambaran diri yang negative menyebabkan perubahan persepsi seseorang dalam memandang aspek positif lain yang dimiliki (Prabowo, 2014).

Peran merupakan bagian terpenting dari konsep diri secara utuh. Peran yang terlalu banyak dapat menjadi beban bagi kehidupan seseorang, hal ini akan berpengaruh terhadap kerancuan dari peran dirinya dan dapat menimbulkan depresi yang berat. Ideal diri adalah harapan, cita-cita serta tujuan yang ingin diwujudkan atau dicapai dalam hidup secara realistis. Identitas diri terkait dengan kemampuan seseorang dalam mengenal siapa dirinya, dengan segala keunikannya. Harga diri merupakan kemampuan seseorang untuk menghargai diri sendiri serta member penghargaan terhadap kemampuan orang lain (Erviana, 2018).

Klien yang mengalami halusinasi memandang dirinya secara negatif sering mengabaikan gambaran dirinya, tidak memperhatikan kebutuhannya dengan baik. Intelektualitas ditentukan oleh tingkat pendidikan seseorang, pengalaman dan interaksi dengan lingkungan ketika mengalami halusinasi. Kepribadian pada klien halusinasi biasanya ditemukan klien memiliki kepribadian yang tertutup. Klien tidak mudah menerima masukan dan informasi yang berkaitan dengan kehidupan klien. Klien juga jarang bergaul dan cenderung menutup diri. Klien memiliki ketidakmampuan untuk mengevaluasi atau menilai keadaan dirinya dan tidak mampu memutuskan melakukan peningkatan keadaan menjadi lebih baik (Nyurimah, 2014).

Moralitas pandangan negatif terhadap diri sendiri ini menyebabkan klien mengalami penurunan motivasi untk melakukan aktifitas. Kesimpulannya, adanya penilaian diri yang negatif pada diri klien dengan halusinasi menyebabkan tidak ada tanggung jawab secara moral pada klien untuk melakukan aktifitas. Menurut beberapa penjelasan di atas dapat diambil suatu kesimpulan bahwa jika mempunyai pengalaman masa lalu yang tidak menyenangkan, klien mempunyai konsep diri negatif, intelektualitas yang rendah, kepribadian dan moralitas yang tidak adekuat merupakan penyebab secara psikologis untuk terjadinya halusinasi. Klien halusinasi memerlukan perhatian yang cukup besar untuk dapat mengembalikan konsep diri yang seutuhnya yang menyebabkan klien suka menyendiri, melamun dan akhirnya muncul halusinasi (Prabowo, 2014). 


\section{d. Sosial Budaya}

Meliputi status sosial, umur, pendidikan, agama, dan kondisi politik. Menurut Nyumirah, 2013 ada beberapa hal yang dikaitkan dengan masalah gangguan jiwa. Salah satunya yang terjadi pada klien halusinasi adalah masalah pekerjaan yang akan mempengaruhi status sosial. Klien dengan status sosial ekonomi yang rendah berpeluang lebih besar untuk mengalami gangguan jiwa dibandingkan dengan klien yang memiliki status sosial ekonomi tinggi (Lukitasari, 2013).

e. Faktor Sosial

Ekonomi tersebut meliputi kemiskinan, tidak memadainya sarana dan prasarana, tidak adekuatnya pemenuhan nutrisi, rendahnya pemenuhan kebutuhan perawatan untuk anggota keluarga, dan perasaan tidak berdaya. Kultur atau budaya, kepercayaan kebudayaan klien dan nilai pribadi mempengaruhi masalah klien dengan halusinasi. Berdasarkan beberapa pernyataan tersebut dapat disimpulkan bahwa status social ekonomi, pendidikan yang rendah, kurangnya pengetahuan, motivasi yang kurang dan kondisi fisik yang lemah dapat mempengaruhi klien dalam mempertahankan aktifitas klien yang mengalami halusinasi (Latifah, 2019).

\section{Faktor Presipitasi}

Secara umum klien dengan gangguan halusinasi timbul gangguan setelah adanya hubungan yang bermusuhan, tekanan, isolasi, perasaan tidak berguna, putus asa dan tidak berdaya. Penilaian individu terhadap stressor dan masalah koping dapat mengindikasikan kemungkinan kekambuhan (Keliat, 2014). Faktor presipitasi sebagai suatu stimulus yang dipersepsikan oleh individu apakah dipersepsikan sebagai suatu kesempatan, tantangan, ancaman/tuntutan. Stressor presipitasi bisa berupa stimulus internal maupun eksternal yang mengancam individu. Komponen stressor presipitasi terdiri atas sifat, asal, waktu dan jumlah stressor (Stuart, 2013). Sifat stresor, terjadinya halusinasi berdasarkan sifat terdiri dari (Jelika, 2015) :

a. Komponen biologis, misalnya penyakit infeksi, penyakit kronis atau kelainan struktur otak, ketidakteraturan dalam proses pengobatan.

b. Komponen psikologis, misalnya: intelegensi, ketrampilan verbal, moral, kepribadian dan kontrol diri, pengalaman yang tidak menyenangkan, kurangnya motivasi.

c. Komponen sosial budaya, misalnya: adanya aturan yang sering bertentangan 
antara individu dan kelompok masyarakat, tuntutan masyarakat yang tidak sesuai dengan kemampuan seseorang, ataupun adanya stigma dari masyarakat terhadap seseorang yang mengalami gangguan jiwa, sehingga klien melakukan perilaku yang terkadang menentang hal tersebut yang menurut masyarakat tidak sesuai dengan kebiasaan dan lingkungan setempat (Nyumirah, 2013).

Asal stresor terdiri dari internal dan eksternal. Stresor internal atau yang berasal dari diri sendiri seperti persepsi individu yang tidak baik tentang dirinya, orang lain dan lingkungannya, merasa tidak mampu, ketidakberdayaan. Stresor eksternal atau berasal dari luar diri seperti kurangnya dukungan keluarga, dukungan masyarakat, dukungan kelompok/teman sebaya, dan lain-lain. Waktu dilihat sebagai dimensi kapan stresor mulai terjadi dan berapa lama terpapar stressor sehingga menyebabkan munculnya gejala. Lama dan jumlah stresor yaitu terkait dengan sejak kapan, sudah berapa lama, berapa kali kejadiannya (frekuensi) serta jumlah stresor (Stuart, 2013).

Saat pertama kali terkena masalah, maka penanganannya juga memerlukan suatu upaya yang lebih intensif dengan tujuan untuk pencegahan primer. Frekuensi dan jumlah stresor juga mempengaruhi individu, bila frekuensi dan jumlah stresor lebih sedikit juga akan memerlukan penanganan yang berbeda dibandingkan dengan yang mempunyai frekuensi dan jumlah stresor lebih banyak. Berbagai penyebab/stressor di atas, yang meliputi stressor predisposisi dan stressor presipitasi yang dialami oleh klien halusinasi akan memunculkan beberapa respon. Respon tersebut merupakan pikiran, sikap, tanggapan, perasaan dan perilaku yang ditunjukkan pada klien halusinasi terhadap kejadian yang dialami (Hidayat, 2015).

\subsubsection{Tanda Dan Gejala}

Menurut Yuanita (2019). Tanda dan gejala Halusinasi terdiri dari:

a. Menarik diri dari orang lain, dan berusaha untuk menghindar diri dari oranglain

b. Tersenyum sendiri, tertawa sendiri

c. Duduk terpukau (berkhayal)

d. Bicara sendiri

e. Memandang satu arah, menggerakan bibir tanpa suara, penggerakan mata yang cepat, dan respon verbal yang lambat

f. Menyerang, sulit berhubungan dengan orang lain 
g. Tiba-tiba marah, curiga, bermusuhan, merusak (diri sendiri, orang lain dan lingkungan) takut

h. Gelisah, ekspresi muka tegang, mudah tersinggung, jengkel

i. Terjadi peningkatan denyut jantung,pernapasan dan tekanan darah

\subsubsection{Rentang Respon Halusinasi}

Halusinasi merupakan salah satu respon maladaptif individu yang berada dalam rentang respon neurobiologis (Stuart \& Laraia, 2015). Ini merupakan respon persepsi paling maladaptif.Jika klien sehat maka persepsi nya akurat, mampu mengidentifikasi dan menginterfrestasikans timulus berdasarkan informasi yang diterima melalui pancaindra pendengaran, penglihatan, penghidu, pengecapan, dan perabaan), klien dengan halusinasi mempersepsikan suatu stimulus panca indra walaupun sebenarnya stimulus tersebut tidak ada. Respon individu (yang karena suatu hal mengalami kelainan persepsi) yaitu salah mempersepsikan stimulus yang diterimanya yang disebut dengan ilusi. Klien mengalami ilusi jika interpretasi yang dilakukan terhadap stimulus panca indera tidak akurat sesuai dengan stimulus yang diterima. Respon tersebut digambarkan seperti gambar diatas. (Erliyani, 2019).

Rentang Respon neurobiologis

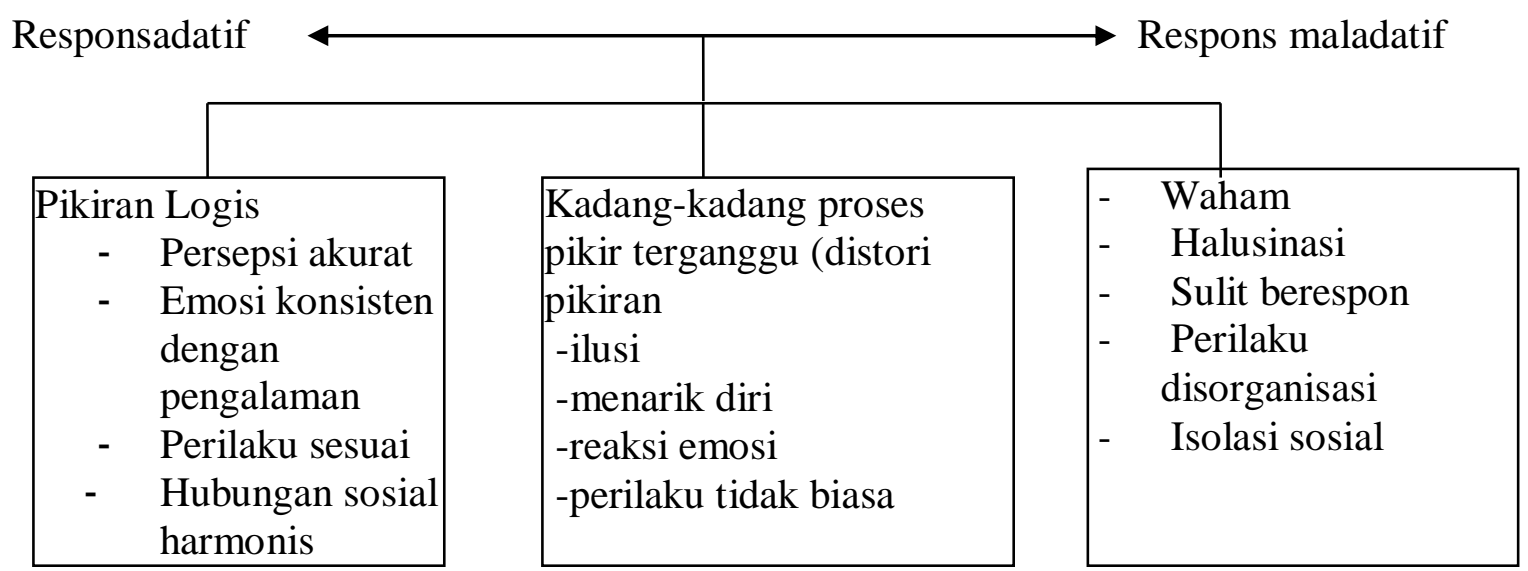

Rentang respon neurobiologist halusinasi (Muhith,2015).

\subsubsection{Jenis -Jenis Halusinasi}

Menurut Stuart (2013 dalam Yusalia, 2015), jenis halusinasi antara lain :

1. Halusinasi pendengaran (auditorik) $70 \%$

Karakteristik ditandai dengan mendengar suara, teruatama suara - suara orang, biasanya klien mendengar suara orang yang sedang membicarakan apa yang sedang dipikirkannya dan memerintahkan untuk melakukan sesuatu. 
2. Halusinasi penglihatan (visual) $20 \%$

Karakteristik dengan adanya stimulus penglihatan dalam bentuk pancaran cahaya, gambaran geometrik, gambar kartun dan / atau panorama yang luas dan kompleks. Penglihatan bisa menyenangkan atau menakutkan.

3. Halusinasi penghidu (olfactory)

Karakteristik ditandai dengan adanya bau busuk, amis dan bau yang menjijikkan seperti: darah, urine atau feses. Kadang - kadang terhidu bau harum. Biasanya berhubungan dengan stroke, tumor, kejang dan dementia.

4. Halusinasi peraba (tactile)

Karakteristik ditandai dengan adanya rasa sakit atau tidak enak tanpa stimulus yang terlihat. Contoh : merasakan sensasi listrik datang dari tanah, benda mati atau orang lain.

5. Halusinasi pengecap (gustatory)

Karakteristik ditandai dengan merasakan sesuatu yang busuk, amis dan menjijikkan, merasa mengecap rasa seperti rasa darah, urin atau feses.

6. Halusinasi cenesthetik

Karakteristik ditandai dengan merasakan fungsi tubuh seperti darah mengalir melalui vena atau arteri, makanan dicerna atau pembentukan urine.

7. Halusinasi kinesthetic

Merasakan pergerakan sementara berdiri tanpa bergerak.

\subsubsection{Penatalaksanaan Halusinasi}

Menurut Keliat (2014) dalam Pambayun (2015), tindakan keperawatan untuk membantu klien mengatasi halusinasinya dimulai dengan membina hubungan saling percaya dengan klien. Hubungan saling percaya sangat penting dijalin sebelum mengintervensi klien lebih lanjut. Pertama-tama klien harus difasilitasi untuk merasa nyaman menceritakan pengalaman aneh halusinasinya agar informasi tentang halusinasi yang dialami oleh klien dapat diceritakan secara konprehensif. Untuk itu perawat harus memperkenalkan diri, membuat kontrak asuhan dengan klien bahwa keberadaan perawat adalah betul-betul untuk membantu klien. Perawat juga harus sabar, memperlihatkan penerimaan yang tulus, dan aktif mendengar ungkapan klien saat menceritakan halusinasinya. Hindarkan menyalahkan klien atau menertawakan klien walaupun pengalaman halusinasi yang diceritakan aneh dan menggelikan bagi perawat. Perawat harus 
bisa mengendalikan diri agar tetap terapeutik.

Setelah hubungan saling percaya terjalin, intervensi keperawatan selanjutnya adalah membantu klien mengenali halusinasinya (tentang isi halusinasi, waktu, frekuensi terjadinya halusinasi, situasi yang menyebabkan munculnya halusinasi, dan perasaan klien saat halusinasi muncul). Setelah klien menyadari bahwa halusinasi yang dialaminya adalah masalah yang harus diatasi, maka selanjutnya klien perlu dilatih bagaimana cara yang bisa dilakukan dan terbukti efektif mengatasi halusinasi. Proses ini dimulai dengan mengkaji pengalaman klien mengatasi halusinasi. Bila ada beberapa usaha yang klien lakukan untuk mengatasi halusinasi, perawat perlu mendiskusikan efektifitas cara tersebut. Apabila cara tersebut efektif, bisa diterapkan, sementara jika cara yang dilakukan tidak efektif perawat dapat membantu dengan cara-cara baru.

Menurut Keliat (2014), ada beberapa cara yang bisa dilatihkan kepada klien untuk mengontrol halusinasi, meliputi :

1. Menghardik halusinasi.

Halusinasi berasal dari stimulus internal. Untuk mengatasinya, klien harus berusaha melawan halusinasi yang dialaminya secara internal juga. Klien dilatih untuk mengatakan, "tidak mau dengar..., tidak mau lihat". Ini dianjurkan untuk dilakukan bila halusinasi muncul setiap saat. Bantu pasien mengenal halusinasi, jelaskan cara-cara kontrol halusinasi, ajarkan pasien mengontrol halusinasi dengan cara pertama yaitu menghardik halusinasi:

2. Menggunakan obat.

Salah satu penyebab munculnya halusinasi adalah akibat ketidakseimbangan neurotransmiter di syaraf (dopamin, serotonin). Untuk itu, klien perlu diberi penjelasan bagaimana kerja obat dapat mengatasi halusinasi, serta bagairnana mengkonsumsi obat secara tepat sehingga tujuan pengobatan tercapai secara optimal. Pendidikan kesehatan dapat dilakukan dengan materi yang benar dalam pemberian obat agar klien patuh untuk menjalankan pengobatan secara tuntas dan teratur.

Keluarga klien perlu diberi penjelasan tentang bagaimana penanganan klien yang mengalami halusinasi sesuai dengan kemampuan keluarga. Hal ini penting dilakukan dengan dua alasan. Pertama keluarga adalah sistem di mana 
klien berasal. Pengaruh sikap keluarga akan sangat menentukan kesehatan jiwa klien. Klien mungkin sudah mampu mengatasi masalahnya, tetapi jika tidak didukung secara kuat, klien bisa mengalami kegagalan, dan halusinasi bisa kambuh lagi. Alasan kedua, halusinasi sebagai salah satu gejala psikosis bisa berlangsung lama (kronis), sekalipun klien pulang ke rumah, mungkin masih mengalarni halusinasi. Dengan mendidik keluarga tentang cara penanganan halusinasi, diharapkan keluarga dapat menjadi terapis begitu klien kembali ke rumah. Latih pasien menggunakan obat secara teratur:

Jenis-jenis obat yang biasa digunakan pada pasien halusinasi adalah:

a). Clorpromazine ( CPZ, Largactile ), Warna : Orange

\section{Indikasi:}

Untuk mensupresi gejala-gejala psikosa : agitasi, ansietas, ketegangan, kebingungan, insomnia, halusinasi, waham, dan gejala-gejala lain yang biasanya terdapat pada penderita skizofrenia, manik depresi, gangguan personalitas, psikosa involution, psikosa masa kecil.

\section{Cara pemberian:}

Untuk kasus psikosa dapat diberikan per oral atau suntikan intramuskuler.

Dosis permulaan adalah 25-100 mg dan diikuti peningkatan dosis hingga mencapai $300 \mathrm{mg}$ perhari. Dosis ini dipertahankan selama satu minggu. Pemberian dapat dilakukan satu kali pada malam hari atau dapat diberikan tiga kali sehari. Bila gejala psikosa belum hilang, dosis dapat dinaikkan secara perlahan-lahan sampai 600-900 mg perhari.

\section{Kontra indikasi:}

Sebaiknya tidak diberikan kepada klien dengan keadaan koma, keracunan alkohol, barbiturat, atau narkotika, dan penderita yang hipersensitif terhadap derifat fenothiazine.

Efek samping:

Yang sering terjadi misalnya lesu dan mengantuk, hipotensi orthostatik, mulut kering, hidung tersumbat, konstipasi, amenore pada wanita, hiperpireksia atau hipopireksia, gejala ekstrapiramida. Intoksikasinya untuk penderita non psikosa dengan dosis yang tinggi menyebabkan gejala penurunan kesadaran karena depresi susunan syaraf pusat, hipotensi,ekstrapiramidal, agitasi, konvulsi, dan perubahan gambaran 
irama EKG. Pada penderita psikosa jarang sekali menimbulkan intoksikasi.

b). Haloperidol ( Haldol, Serenace ), Warna : Putih besar

Indikasi:

Yaitu manifestasi dari gangguan psikotik, sindroma gilies de la tourette pada anak-anak dan dewasa maupun pada gangguan perilaku yang berat pada anak -anak.

\section{Cara pemberian:}

Dosis oral untuk dewasa 1-6 mg sehari yang terbagi menjadi $6-15 \mathrm{mg}$ untuk keadaan berat. Dosis parenteral untuk dewasa $2 \quad-5 \quad \mathrm{mg}$ intramuskuler setiap 1- 8 jam, tergantung kebutuhan.

Kontra indikasi:

Depresi sistem syaraf pusat atau keadaan koma, penyakit parkinson, hipersensitif terhadap haloperidol.

Efek samping:

Yang sering adalah mengantuk, kaku, tremor, lesu, letih, gelisah, gejala ekstrapiramidal atau pseudoparkinson. Efek samping yang jarang adalah nausea, diare, kostipasi, hipersalivasi, hipotensi, gejala gangguan otonomik. Efek samping yang sangat jarang yaitu alergi, reaksi hematologis. Intoksikasinya adalah bila klien memakai dalam dosis melebihi dosis terapeutik dapat timbul kelemahan otot atau kekakuan, tremor, hipotensi, sedasi, koma, depresi pernapasan.

c). Trihexiphenidyl ( THP, Artane, Tremin ), Warna: Putih kecil Indikasi:

Untuk penatalaksanaan manifestasi psikosa khususnya gejala skizofrenia.

\section{Cara pemberian:}

Dosis dan cara pemberian untuk dosis awal sebaiknya rendah ( $12,5 \mathrm{mg}$ ) diberikan tiap 2 minggu. Bila efek samping ringan, dosis ditingkatkan 25 mg dan interval pemberian diperpanjang 3-6 mg setiap kali suntikan, tergantung dari respon klien. Bila pemberian melebihi $50 \mathrm{mg}$ sekali suntikan sebaiknya peningkatan perlahan-lahan.

Kontra indikasi: 
Pada depresi susunan syaraf pusat yang hebat, hipersensitif terhadap fluphenazine atau ada riwayat sensitif terhadap phenotiazine. Intoksikasi biasanya terjadi gejala-gejala sesuai dengan efek samping yang hebat. Pengobatan over dosis ; hentikan obat berikan terapi simtomatis dan suportif, atasi hipotensi dengan levarteronol hindari menggunakan ephineprine ISO, (2008) dalam Pambayun (2015).

3. Berinteraksi dengan orang lain.

Klien dianjurkan meningkatkan keterampilan hubungan sosialnya. Dengan meningkatkan intensitas interaksi sosialnya, kilen akan dapat memvalidasi persepsinya pada orang lain. Klien juga mengalami peningkatan stimulus eksternal jika berhubungan dengan orang lain. Dua hal ini akan mengurangi fokus perhatian klien terhadap stimulus internal yang menjadi sumber halusinasinya. Latih pasien mengontrol halusinasi dengan cara kedua yaitu bercakap-cakap dengan orang lain.

4. Beraktivitas secara teratur dengan menyusun kegiatan harian.

Kebanyakan halusinasi muncul akibat banyaknya waktu luang yang tidak dimanfaatkan dengan baik oleh klien. Klien akhirnya asyik dengan halusinasinya. Untuk itu, klien perlu dilatih menyusun rencana kegiatan dari pagi sejak bangun pagi sampai malam menjelang tidur dengan kegiatan yang bermanfaat. Perawat harus selalu memonitor pelaksanaan kegiatan tersebut sehingga klien betul-betul tidak ada waktu lagi untuk melamun tak terarah. Latih pasien mengontrol halusinasi dengan cara ketiga, yaitu melaksanakan aktivitas terjadwal.

\subsection{Konsep Dasar Asuhan Keperawatan}

\subsubsection{Pengkajian}

Pengkajian merupakan pengumpulan data subjektif dan objektif secara, sistematis dengan tujuan membuat penentuan tindakan keperawatan bagi individu, keluarga dan komunitas (Damayanti \& Iskandar,2014). Pada tahap ini ada beberapa yang perlu dieksplorasi baik pada klien yang berkenaan dengan kasus halusinasi yang meliputi: 
a. Identitas klien

Meliputi nama klien, umur, jenis kelamin, status perkawinan, Agama, tanggal MRS,informan,tanggal pengkajian, nomor rumah klien, dan alamat klien.

b. Keluhan utama

Keluhan utama biasanya berupa bicara sendiri, tertawa sendiri, senyum sendiri, menggerakkan bibir tanpa suara, menarik diri dari orang lain, tidak dapat membedakan yang nyata dan tidak nyata, ekspresi muka tegang mudah tersinggung, jengkel dan marah ketakutan biasa terdapat disorientasi waktu tempat dan orang, tidak dapat mengurus diri dan tidak melakukan kegiatan sehari-hari.

c. Faktor predisposisi

Faktor predisposisi adalah faktor resiko yang mempengaruhi jenis dan jumlah sumber yang dapat dibangkitkan oleh individu untuk mengatasi stres. Diperoleh baik dari klien maupun keluarganya, mengenai faktor perkembangan sosial kultural, biokimia psikologis dan genetik yaitu faktor resiko yang mempengaruhi jenis dan jumlah sumber yang dapat dibangkitkan oleh individu untuk mengatasi stres.

1. Faktor perkembangan;biasanya tugas perkembangan mengalami hambatan dan hubungan interpersonal terganggu maka individu akan mengalami stres dan kecemasan (Susilawati,2019)

2. Faktor sosiokultural ; berbagai faktor di masyarakat dapat menyebab kanseseorang merasa disingkirkan oleh kesepian terhadap lingkungan tempat klien dibesarkan.

3. Faktor biokimia ; adanya stres yang berlebihan dialami seseorang maka didalam tubuh akan dihasilkan suatu zat yang dapat bersifat halusinogenik neurokimia.

4. Faktor psikologis; hubungan interpersonal yangtidak harmonis, adanya peranganda yang bertentangan dan tidak diterima oleh anak akan mengakibatkan stres dan kecemasan yang tinggi dan berakhir dengan gangguan orientasi realitas seperti halusinasi (Erviana, 2018)

5. Faktor genetik; Apa yang berpengaruh dalam skizoprenia. Belum diketahui, tetapi hasil studi menunjukkan bahwa faktor keluarga menunjukkan hubungan yang sangat berpengaruh pada penyakit ini. 
d. Faktor presipitasi

Adanya rangsangan lingkungan yang sering yaitu seperti partisipasi klien dalam kelompok, terlalu lama diajak komunikasi objek yang ada dilingkungan juga suasana sepi/isolasi adalah sering sebagai pencetus terjadinya halusinasi karena hal tersebut dapat meningkatkan stres dan kecemasan yang merangsang tubuh mengeluarkan zat halusinogenik (Yusuf, 2015)

e. Aspek fisik

Hasil pengukuran tanda vital (TD, nadi, suhu, pernapasan, TB,BB) dan keluhan fisik yang dialami oleh klien.Terjadi peningkatan denyut jantung pernapasan dan tekanan darah.

f. Aspek psikososial

Genogram yang menggambarkan tiga generasi.

g. Konsep diri (Zuraida, 2018)

1. Citra tubuh

Menolak melihat dan menyentuh bagian tubuh yang berubah/ tidakmenerima perubahan tubuh yang terjadi / yang akan terjadi. Menolak penjelasan perubahan tubuh, persepsi negatif tentang tubuh. Preokupasi dengan bagian tubuh yang hilang, mengungkapkan keputusasaan, mengungkapkan ketakutan.

2. Identitas diri

Ketidakpastian memandang diri, sukar menetapkan keinginan dan tidak mampu mengambil keputusan.

3. Peran

Berubah / berhenti fungsi peran yang disebabkan penyakit, proses menua, putus sekolah dan PHK.

4. Identitas diri

Mengungkapkan keputusasaan karena penyakitnya dan mengungkapkan keinginan yang terlalu tinggi

5. Harga diri

Perasaan malu terhadap diri sendiri, rasa bersalah terhadap diri sendiri, gangguan hubungan sosial, merendahkan martabat, mencederai diri dan kurang percaya diri. 
h. Status mental

Pada pengkajian status mental pasien halusinasi ditemukan data berupa bicara sendiri, senyum sendiri, tertawa sendiri, menggerakkan bibir tanpasuara, pergerakan mata yang cepat, respon verbal yang lambat, menarik diri dari orang lain berusaha untuk menghindari orang lain, tidak dapat membedakan yang nyata dan tidak nyata, terjadi peningkatan denyut jantung pernapasan dan tekanan darah, perhatian dengan lingkungan yang kurang/ hanya beberapa detik com berkonsentrasi dengan pengalaman sensori, sulit berhubungan dengan orang lain, ekspresi muka tegang, mudah tersinggung, jengkel dan marah tidak mampu mengikuti perintah dari perawat, tampak tremor dan berkeringat, perilaku panik, agitasi dan kata ton curiga dan bermusuhan, bertindak merusak diri orang lain dan lingkungan, ketakutan, tidak dapat mengurus diri, biasa terdapat disorientasi waktu tempat dan orang (Erviana,2018)

i. Mekanisme koping Apabila mendapat masalah, pasien takut / tidak mau menceritakan kepada orang lain (koping menarik diri). Mekanisme koping yang digunakan pasien sebagai usaha mengatasi kecemasan yang merupakan suatu kesepian nyata yang mengancam dirinya. Mekanisme koping yang sering digunakan pada halusinasi adalah (Prabowo, 2014) :

1. Regresi: menjadi malas beraktivitas sehari-hari.

2. Proyeksi : menjelaskan perubahan suatu persepsi dengan berusaha untuk mengalihkan tanggung jawab kepada oranglain.

3. Menarik diri : sulit mempercayai orang lain dan asyik dengan stimulus internal.

j. Aspek medik

Terapi yang diterima klien bisa berupa terapi farmakologi psikomotor terapi okupasional, TAK dan rehabilitas.

\subsubsection{Diagnosa Keperawatan}

Menurut NANDA (2017) diagnosa keperawatan utama pada klien dengan prilaku halusinasi adalah Gangguan sensori persepsi: Halusinasi (pendengaran, penglihatan, pengecapan, perabaan dan penciuman). Sedangkan diagnosa keperawatan terkait lainnya adalah Isolasi sosial dan Resiko menciderai diri 
sendiri, lingkungan dan orang lain.

\subsubsection{Perencanaan Keperawatan}

Rencana tindakan pada keluarga (Husein,\&Arifin,2015) adalah;

1. Diskusikan masalah yang dihadap keluarga dalam merawat pasien

2. Berikan penjelasan meliputi: pengertian halusinasi, proses terjadinya halusinasi, jenis halusinasi yang dialami, tanda dan gejala halusinasi, proses terjadinya halusinasi.

3. Jelaskan dan latih cara merawat anggota keluarga yang mengalami halusinasi : menghardik, minum obat, bercakap-cakap, melakukan aktivitas.

4. Diskusikan cara menciptakan lingkungan yang dapat mencegah terjadinya halusinasi.

5. Diskusikan tanda dan gejala kekambuhan

6. Diskusikan pemanfaatan fasilitas pelayanan kesehatan terdekat untuk followup anggota keluarga dengan halusinasi.

Rencana tindakan keperawatan pada klien dengan diagnosa gangguan persepsi sensori halusinasi meliputi pemberian tindakan keperawatan berupa terapi (Sulah, Pratiwi, \& Teguh. 2016) yaitu :

1. Bantu klien mengenal halusinasinya meliputi isi, waktu terjadi halusinasi, isi, frekuensi, perasaan saat terjadi halusinasi respon klien terhadap halusinasi mengontrol halusinasi dengan cara menghardik.

2. Meminum obat secara teratur.

3. Melatih bercakap-cakap dengan orang lain.

4. Menyusun kegiatan terjadwal dan dengan aktifitas

\subsubsection{Implementasi Keperawatan}

Disesuaikan dengan rencana tindakan keperawatan. Pada situasi nyata sering pelaksanaan jauh berbeda dengan rencana, hal ini terjadi karena perawat belum terbiasa menggunakan rencana tertulis dalam melaksanakan tindakan keperawatan. Sebelum melaksanakan tindakan keperawatan yang sudah direncanakan, perawat perlu memvalidasi dengan singkat apakah rencana tindakan masih sesuai dan dibutuhkan klien sesuai dengan kondisinya (here and now). Perawat juga menilai diri sendiri, apakah kemampuan interpersonal, intelektual, tekhnikal sesuai dengan 
tindakan yang akan dilaksanakan, dinilai kembali apakah aman bagi klien. Setelah semuanya tidak ada hambatan maka tindakan keperawatan boleh dilaksanakan (Andri, 2019)

Adapun pelaksanaan tindakan keperawatan jiwa dilakukan berdasarkan. Strategi Pelaksanaan (SP) yang sesuai dengan masing-masing masalah utama. Pada masalah gangguan sensori persepsi: halusinasi pendengaran, terdapat 2 jenis SP, yaitu SP Klien dan SP Keluarga. SP klien terbagi menjadi SP 1 (membina hubungan saling percaya, mengidentifikasi halusinasi “jenis, isi, waktu, frekuensi, situasi, perasaan dan respon halusinasi”, mengajarkan cara menghardik, memasukan cara menghardik ke dalam jadwal; SP 2 (mengevaluasi SP 1, mengajarkan cara minum obat secara teratur, memasukan ke dalam jadwal); SP 3 (mengevaluasi SP 1 dan SP 2, menganjurkan klien untuk mencari teman bicara); SP 4 (mengevaluasi SP 1, SP 2, dan SP 3, melakukan kegiatan terjadwal). SP keluarga terbagi menjadi SP 1 (membina hubungan saling percaya, mendiskusikan masalah yang dihadapi keluarga dalam merawat pasien, menjelaskan pengertian, tanda dan gejala helusinasi, jenis halusinasi yang dialami klien beserta proses terjadinya, menjelaskan cara merawat pasien halusinasi); SP 2 (melatih keluarga mempraktekan cara merawat pasien dengan halusinasi, melatih keluarga melakukan cara merawat langsung kepada pasien halusinasi); SP 3 (membantu keluarga membuat jadwal aktivitas di rumah termasuk minum obat (discharge planing), menjelaskan follow up pasien setelah pulang). Pada saatakan dilaksanakan tindakan keperawatan maka kontrak dengan klien dilaksanakan dengan menjelaskan apa yang akan dikerjakan dan peran serta klien yang diharapkan, dokumentasikan semua tindakan yang telah dilaksanakan serta respon klien (Irwan, 2021)

\subsubsection{Evaluasi Keperawatan}

Evaluasi adalah proses hasil atau sumatif dilakukan dengan membandingkan respon klien pada tujuan umum dan tujuan khusus yang telah ditentukan. Halusinasi pendengaran tidak terjadi perilaku kekerasan, klien dapat membina hubungan saling percaya, klien dapat mengenal halusinasinya, klien dapat mengontrol halusinasi dengar dari jangka waktu 4x24 jam didapatkan data subjektif keluarga menyatakan senang karena sudah diajarkan teknik 
mengontrol halusinasi, keluarga menyatakan pasien mampu melakukan beberapa teknik mengontrol halusinasi. Data objektif pasien tampak berbicara sendiri saat halusinasi itu datang, pasien dapat berbincang-bincang dengan orang lain, pasien mampu melakukan aktivitas terjadwal, dan minum obat secara teratur (Hafizudiin,2021). 


\section{BAB 3}

\section{ASUHAN KEPERAWATAN}

\subsection{Identitas Klien}

Inisial $\quad$ :Tn.As

Alamat : Jl. Pengabdian, Dusun III. Batu Bara

Tanggal Pengkajian : 26 Januari 2022

Umur : :26 tahun

Agama : Islam

Status $\quad$ : Belum Menikah

Infoment $\quad$ : Status pasien dan komunikasi dengan pasien

\subsection{Keluhan Utama}

Klien pernah mencoba bunuh diri sebanyak 3x, memukul kaca dan melukai kulitnya dengan api dari puntung rokok hal itu dilakukannya karena mendengar suara-suara bisikan yang menyuruhnya melukai dirinya dan saat suara itu datang klien tidak bisa mengontrol dirinya, klien susah tidur dan klien susah diatur

Masalah Keperawatan : Gangguan Persepsi Sensori : Halusinasi Pendengaran.

\subsection{Faktor Predisposisi}

Klien sebelumnya pernah mengalami gangguan jiwa dan dirawat di RSJ Prof. Dr. M. Ildrem dan pulang dalam keadaan tenang. Dirumah klien tidak teratur minum obat dan tidak mau kontrol kerumah sakit jiwa, sehingga timbul gejala-gejala seperti diatas dan kemudian klien kambuh lagi. Sehingga akhirnya keluarga membawa klien kembali ke RSJ Prof. Dr. M. Ildrem karena klien sangat susah diatur.

Masalah Keperawatan : Koping Individu In efektif

\subsection{Fisik}

Klien tidak memiliki keluhan fisik, saat dilakukan pemeriksaan tanda-tanda vital, didapatkan hasil TD : 120/80mmHg ; $\mathrm{N}: 80 x / \mathrm{i} ; \mathrm{S}: 36,5^{\circ} \mathrm{C}$; RR : 20x/i. Klien memiliki tinggi badan $155 \mathrm{~cm}$ dan berat badan $60 \mathrm{Kg}$.

\subsection{Psikososial}




\section{a. Genogram}

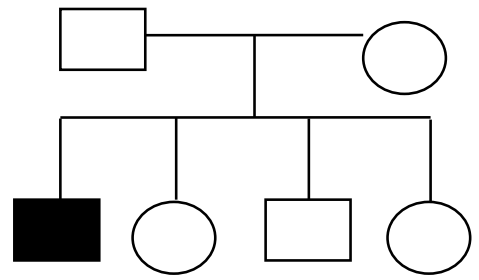

Klien merupakan anak pertama dari 4 bersaudara, klien memiliki 2 adik perempuan dan satu adik laki-laki, klien tinggal bersama kedua orang tua dan adik-adiknya.

$$
\text { : Laki-laki }
$$

$\bigcirc$ : Perempuan

: Klien

\section{b. Konsep diri}
a. Gambaran diri
: Klien tidak suka dengan dirinya karena dibagian kulitnya dipenuhin bekas luka akibat api dari puntung rokok
b. Identitas
: Klien mengatakan nama dan alamat, klien merupakan anak pertama dari 4 bersaudara dan klien hanya tamatan SMA
c. Peran
: Klien sadar karena belum memenuhi perannya sebagai Anak dan sebagai abang yang paling besar
d. Ideal diri
: Klien merasa merepotkan keluarga,klien ingin cepat sembuh dan cepat pulang
e. Harga diri
: Klien merasa malu dan tidak suka dengan dirinya yang sekarang

Masalah keperawatan : Gangguan Konsep Diri : Harga Diri Rendah

\section{c. Hubungan sosial}

1. Orang yang berarti : orang tua dan adik-adiknya

2. Peran serta dalam kegiatan kelompok/masyarakat : Pasien mengatakan tidak mengikuti kegiatan di masyarakat

3. Hambatan dalam berhubungan dengan orang lain : Pasien mengatakan susah berinteraksi di luar lingkungan karena kurang percaya diri dan selalu ingin 
menyendiri.

Masalah Keperawatan : Isolasi Sosial: Menarik diri

\section{d. Spiritual}

1. Nilai dan Keyakinan : Klien beragama islam dan yakin dengan agamanya.

2. Kegiatan Ibadah : Klien jarang melaksakan sholat 5 waktu

\section{e. Status Mental}

1. Penampilan

Penjelasan : Klien berpenampilan bersih dan rapi

2. Pembicaraan

Penjelasan : Klien masih dapat menjawab pertanyaan perawat dengan lambat namun dapat dipahami

3. Aktivitas Motorik

Penjelasan : Klien dapat melakukan aktivitas dengan baik

4. Suasana perasaan

Penjelasan : Klien mengatakan sering merasa takut karena ada mendengar bisikan dari telinga kiri dan kanan yang menyuruh untuk melukai dirinya Masalah keperawatan : Gangguan persepsi sensori: Halusinasi Pendengaran

5. Afek

Penjelasan : afek klien labil,suka diam

Masalah keperawatan : Isolasi sosial

6. Interaksi selama wawancara

Penjelasan : Klien kooperatif, ada kontak mata,tapi pandangan terlihat kosong pada lawan bicara,dan klien terlihat tenang dan mengikuti intruksi.

7. Persepsi

Penjelasan : Klien mengatakan sering mendengar suara - suara disiang dan malam hari ketika sedang sendiri dan istirahat

Masalah keperawatan : Gangguan persepsi sensori : Halusinasi Pendengaran

8. Proses Pikir

Penjelasan : klien mampu menjawab apa yang ditanya dengan baik

9. Isi pikir

Penjelasan : Klien dapat mengontrol isi pikirnya, klien tidak mengalami 
gangguan isi pikir dan tidak ada waham.

10. Memori

Penjelasan :Klien dapat mengingat berapa lama dirawat dan kejadian dalam hidupnya

11. Tingkat kesadaran

Penjelasan : Klien tidak mengalami gangguan orientasi, klien mengenali waktu,orang dan tempat

12. Tingkat konsentrasi berhitung

Penjelasan : klien mampu berkonsentrasi dalam perhitungan sederhana tanpa bantuan orang lain.

13. Kemampuan penilaian

Penjelasan : Klien dapat mengambil keputusan sederhana

14. Daya tilik diri

Penjelasan: Klien menyadari sakitnya dan sering mendengar suara - suara

\subsection{Mekanisme Koping}

Klien mengalami mekanisme koping adaptif yaitu klien dapat berbicara baik dengan orang lain dan berkooperatif.

\subsection{Masalah Psikososial dan Lingkungan}

Klien mengatakan jarang mengikuti kegiatan dilingkungan rumah karena klien merasa malu dan kurang percaya diri

Masalah Keperawatan : Isolasi sosial : Menarik diri

\subsection{Pengetahuan Kurang Tentang Gangguan Jiwa}

Klien mengetahui tentang gangguan jiwa dan klien paham tentang penyakitnya dan apa saja obat yang harus diminum dan kapan saja.

\subsection{Aspek Medik}

Diagnosa Medik : Skizofrenia Paranoid

Terapi medis yang diberikan :

- Risperidone 2mg 2x1

- Clozapine 25mg 1x1 


\subsection{Analisa Data}

\begin{tabular}{|c|c|c|}
\hline No & Analisa Data & Masalah keperawatan \\
\hline 1. & $\begin{array}{ll}\text { DS: } & \\
\text { - Klien mengatakan sering mendengar suara- } \\
\text { suara yang menyuruhnya untuk melukai } \\
\text { dirinya } \\
\text { - Klien mengatakan suara-suara itu muncul } \\
\text { saat siang dan malam hari ketika ia sedang } \\
\text { menyendiri dan saat sedang beristirahat } \\
\text { - Klien mengatakan ketika suara itu muncul } \\
\text { dia membakar kulitnya dengan api dari } \\
\text { puntung rokok } \\
\text { DO: Klien tampak ketakutan ketika suara-suara } \\
\text { - } \text { bisikan itu datang } \\
\text { - Klien tampa bingung karena tidak tau apa } \\
\text { yang harus dilakukannya } \\
\text { Klien tampak gelisah } \\
\text { - Klien tampak senyum-senyum }\end{array}$ & $\begin{array}{l}\text { Gangguan Persepsi Sensori } \\
\text { : Halusinasi Pendengaran }\end{array}$ \\
\hline 2. & $\begin{array}{ll}\text { DS: } & \\
\text { - Klien mengatakan dirinya lebih senang } \\
& \text { untuk menyendiri } \\
\text { - Klien mengatakan tidak mampu untuk } \\
\text { berinteraksi dengan orang sekitarnya karena } \\
\text { malu akan dirinya } \\
\text { - Klien tampak menarik diri } \\
\text { DO: } \\
\text { - Klien tampak menyendiri } \\
\text { - Klien tampak tidak mampu berinteraksi } \\
\text { dengan baik }\end{array}$ & $\begin{array}{l}\text { Isolasi Sosial: Menarik } \\
\text { Diri }\end{array}$ \\
\hline
\end{tabular}




\begin{tabular}{|c|c|c|}
\hline & $\begin{array}{l}\text { - Klien tampak menarik diri dan susah } \\
\text { untuk berkomunikasi } \\
\text { - Klien tampak sedih } \\
\text { - Klien tampak murung }\end{array}$ & \\
\hline 3 & $\begin{array}{l}\text { DS : } \\
\text { - Klien mengatakan merasa malu dan kurang } \\
\text { percaya diri karena kulitnya penuh bekas } \\
\text { luka bakar } \\
\text { - } \quad \text { Klien merasa sedih karena dirawat dirumah } \\
\text { sakit jiwa } \\
\text { - Klien mengatakan hanya menyusahkan } \\
\text { keluarga dan ingin cepat sembuh } \\
\text { DO : } \\
\text { - Klien tampak murung } \\
\text { - Klien lebih banyak diam, menjawab setiap } \\
\text { pertanyaan hanya sekedar } \\
\text { - } \text { Klien tampak sedih karena kondisinya } \\
\text { - } \text { Klien tampak kurang percaya diri } \\
\text { - } \text { Klien tampak mudah tersinggung }\end{array}$ & $\begin{array}{l}\text { Gangguan Konsep Diri } \\
\text { Harga Diri Rendah }\end{array}$ \\
\hline
\end{tabular}

\subsection{Daftar Masalah Keperawatan}

1) Gangguan Konsep Diri : Harga Diri Rendah

2) Gangguan Persepsi Sensori : Halusinasi

3) Isolasi Sosial : Menarik Diri

\subsection{Pohon Masalah}

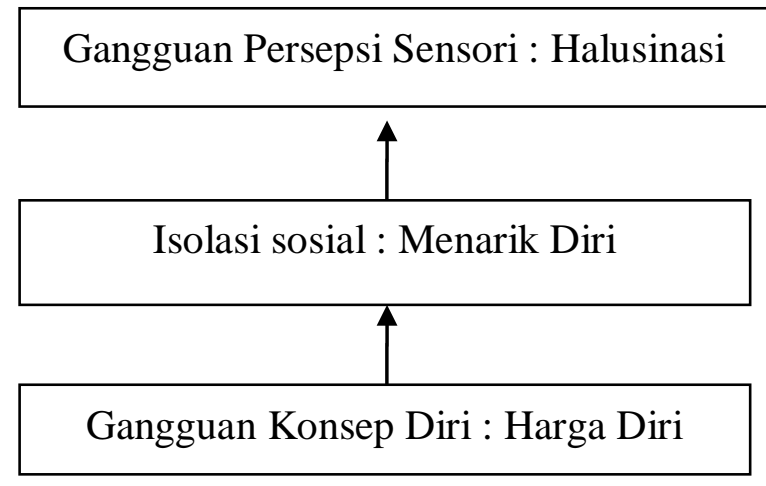




\subsection{Diagnosa Keperawatan}

Gangguan Persepsi Sensori : Halusinasi Pendengaran

\subsection{Intervensi Keperawatan}

\begin{tabular}{|c|c|c|}
\hline No & Diagnosa Keperawatan & Intervensi \\
\hline 1. & $\begin{array}{lll}\text { Gangguan Persepsi } & \text { Sensori } & \text { : } \\
\text { Halusinasi Pendengaran } & & \end{array}$ & $\begin{array}{l}\text { SP 1: } \\
\text { 1. Mengidentifikasi isi, frekuensi, } \\
\text { waktu terjadi, situasi pencetus, } \\
\text { perasaan daan respon halusinasi } \\
\text { 2. Mengontrol halusinasi dengan } \\
\quad \text { menghardik } \\
\text { SP 2: } \\
\text { Mengontrol halusinasi dengan } \\
\text { minum obat secara teratur } \\
\text { SP 3: } \\
\text { Mengontrol halusinasi dengan } \\
\text { bercakap-cakap dengan orang lain } \\
\text { SP 4: } \\
\text { Mengontrol halusinasi dengan } \\
\text { melakukan kegiatan terjadwal }\end{array}$ \\
\hline 2. & Isolasi Sosial : Menarik Diri & $\begin{array}{l}\text { SP 1 : } \\
\text { Menjelaskan keuntungan dan } \\
\text { kerugian mempunyai teman } \\
\text { SP 2 : } \\
\text { Melatih klien berkenalan dengan 2 } \\
\text { orang atau lebih } \\
\text { SP 3 : } \\
\text { Melatih klien bercakap-cakap sambil } \\
\text { melakukan kegiatan harian } \\
\text { SP. 4 : } \\
\text { Melatih klien berbicara social : }\end{array}$ \\
\hline
\end{tabular}




\begin{tabular}{|c|c|c|}
\hline & & $\begin{array}{l}\text { meminta sesuatu,berbelanjadan } \\
\text { sebagainya. }\end{array}$ \\
\hline 3. & $\begin{array}{l}\text { Gangguan Konsep diri : Harga diri } \\
\text { rendah }\end{array}$ & $\begin{array}{l}\text { SP.1 : } \\
\text { Mengidentifikasi kemampuan dan } \\
\text { aspek positif yang dimiliki pasien } \\
\text { SP.2 : } \\
\text { - Menilai kemampuan yang dapat } \\
\quad \text { digunakan } \\
\text { - Menetapkan/memilih kegiatan } \\
\quad \text { sesuai kemampuan } \\
\text { - Melatih } \\
\text { kemampuan yang dipilih } 1 \\
\text { SP.3 : } \\
\text { Melatih Kegiatan sesuai kemampuan } \\
\text { yang dipilih } 2 \\
\text { SP.4 : } \\
\text { Melatih kegiatan sesuai kemampuan } \\
\text { yang dipilih } 3\end{array}$ \\
\hline
\end{tabular}

\subsection{Implementasi Dan Evaluasi}

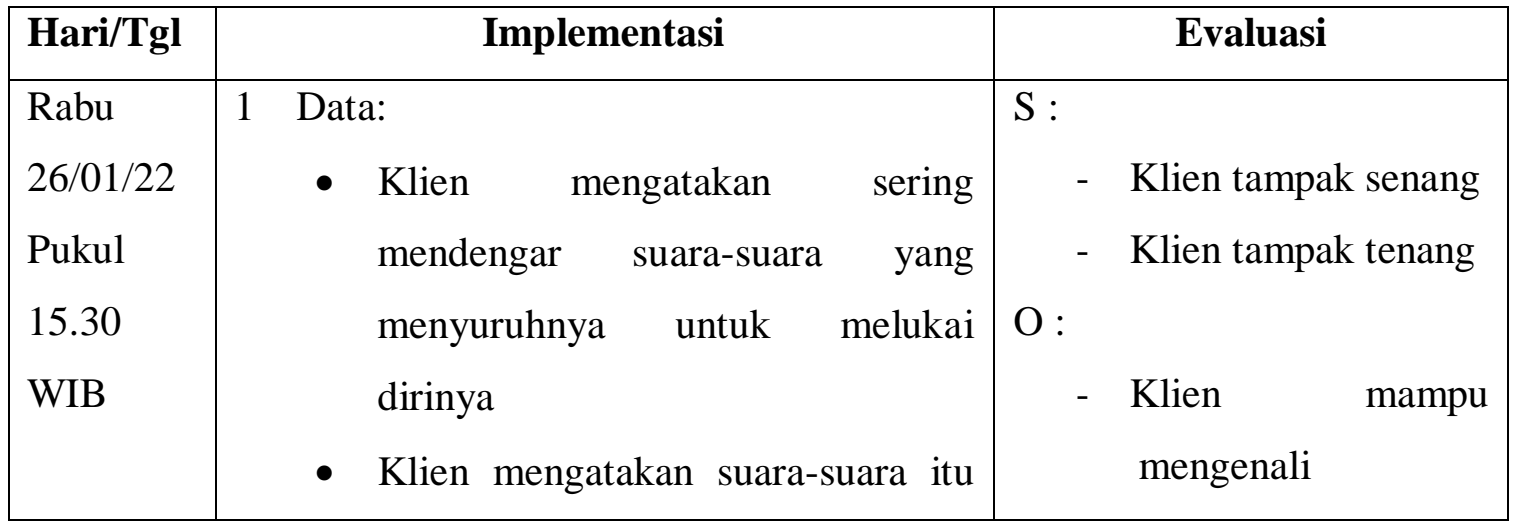




\begin{tabular}{|c|c|c|}
\hline 2 & 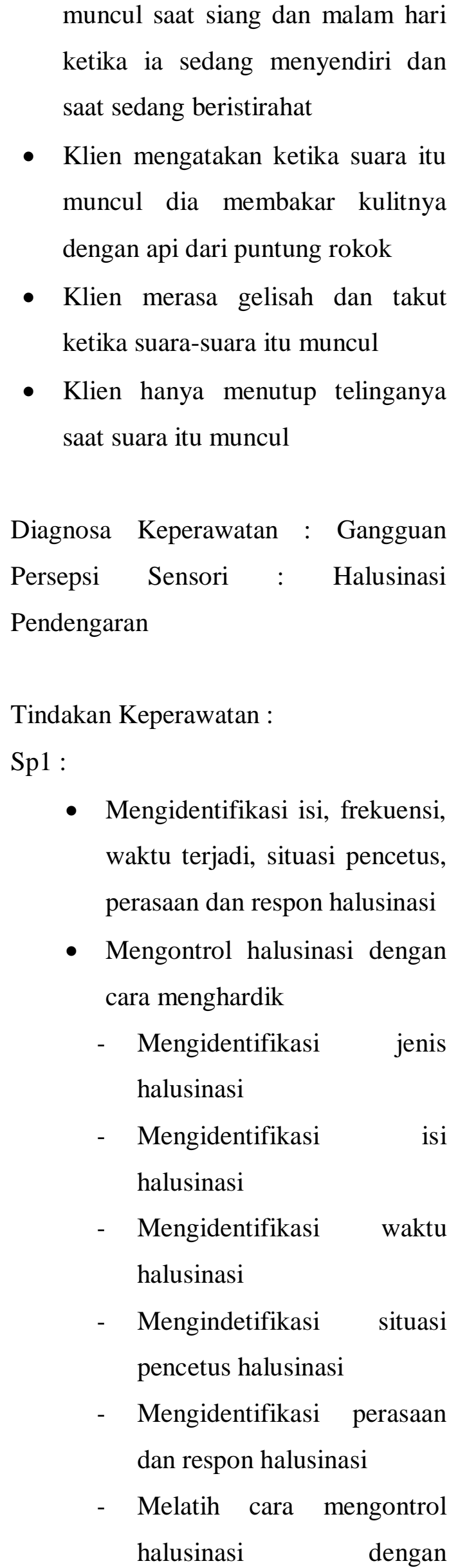 & \begin{tabular}{ll} 
& \multicolumn{2}{l}{ halusinasinya } \\
& dengan dengan \\
& bantuan perawat \\
- & Klien mampu \\
& menghardik \\
& halusinasinya \\
& dengan bantuan \\
& perawat \\
A : Halusinasi Pendengaran \\
(+) \\
P : \\
- \\
Mengenal \\
halusinasinya \\
- Latihan \\
menghardik cara \\
halusinasi $2 \mathrm{x} /$ hari
\end{tabular} \\
\hline
\end{tabular}




\begin{tabular}{|c|c|c|}
\hline & $\begin{array}{l}4 \text { Rencana Tindak Lanjut: } \\
\text { Sp2 : Mengontrol halusinasi dengan minum } \\
\text { obat secara teratur }\end{array}$ & \\
\hline $\begin{array}{l}\text { Kamis } \\
27 / 01 / 22 \\
\text { Jam } \\
15.00\end{array}$ & 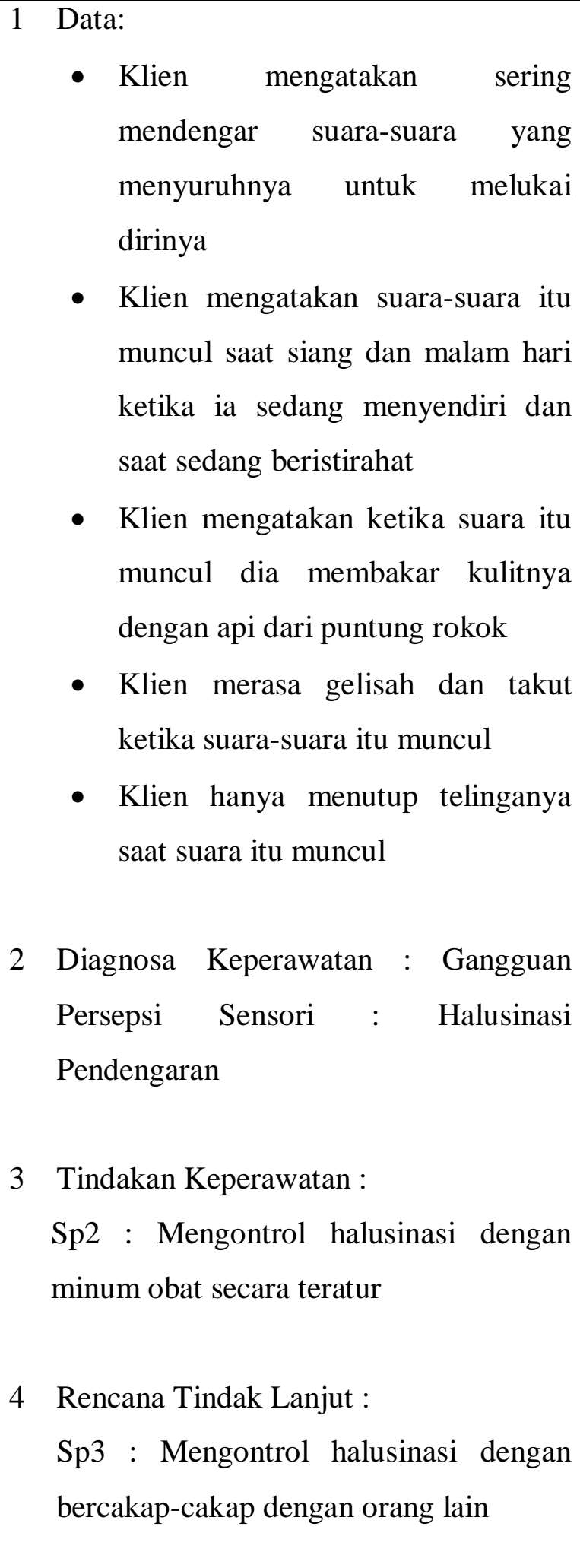 & 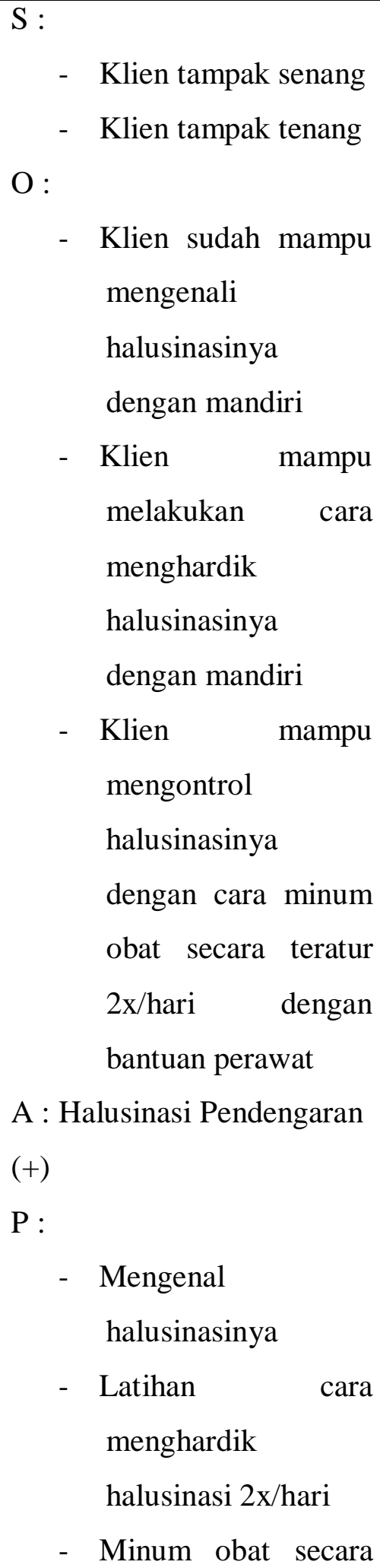 \\
\hline
\end{tabular}




\begin{tabular}{|c|c|c|c|}
\hline & & & teratur $2 \mathrm{x} /$ hari \\
\hline $\begin{array}{l}\text { Jumat } \\
28 / 02 / 22 \\
\text { Jam } \\
15.00\end{array}$ & 1 & $\begin{array}{l}\text { Data: } \\
\text { - Klien mengatakan sering } \\
\text { mendengar suara-suara yang } \\
\text { menyuruhnya untuk melukai } \\
\text { dirinya } \\
\text { - Klien mengatakan suara-suara itu } \\
\text { muncul saat siang dan malam hari } \\
\text { ketika ia sedang menyendiri dan } \\
\text { saat sedang beristirahat } \\
\text { - Klien mengatakan ketika suara itu } \\
\text { muncul dia membakar kulitnya } \\
\text { dengan api dari puntung rokok } \\
\text { Klien merasa gelisah dan takut } \\
\text { melakukan kegiatan terjadwal } \\
\text { ketika suara-suara itu muncul } \\
\text { - Klien hanya menutup telinganya } \\
\text { bercakap-cakap dengan orang lain } \\
\text { Paat suara itu muncul } \\
\text { Pendengaran } \\
\text { Diagnosa Keperawatan : Gangguan } \\
\text { Sensori }\end{array}$ & 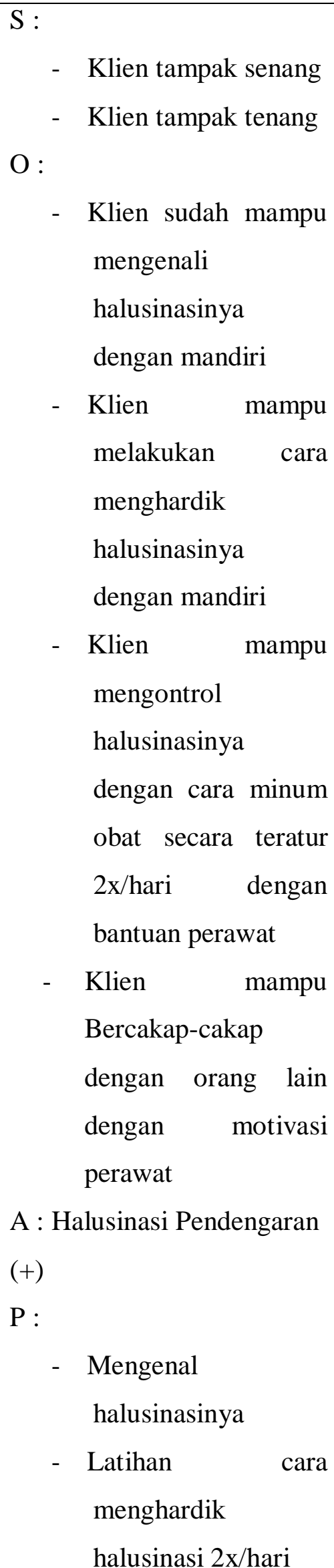 \\
\hline
\end{tabular}




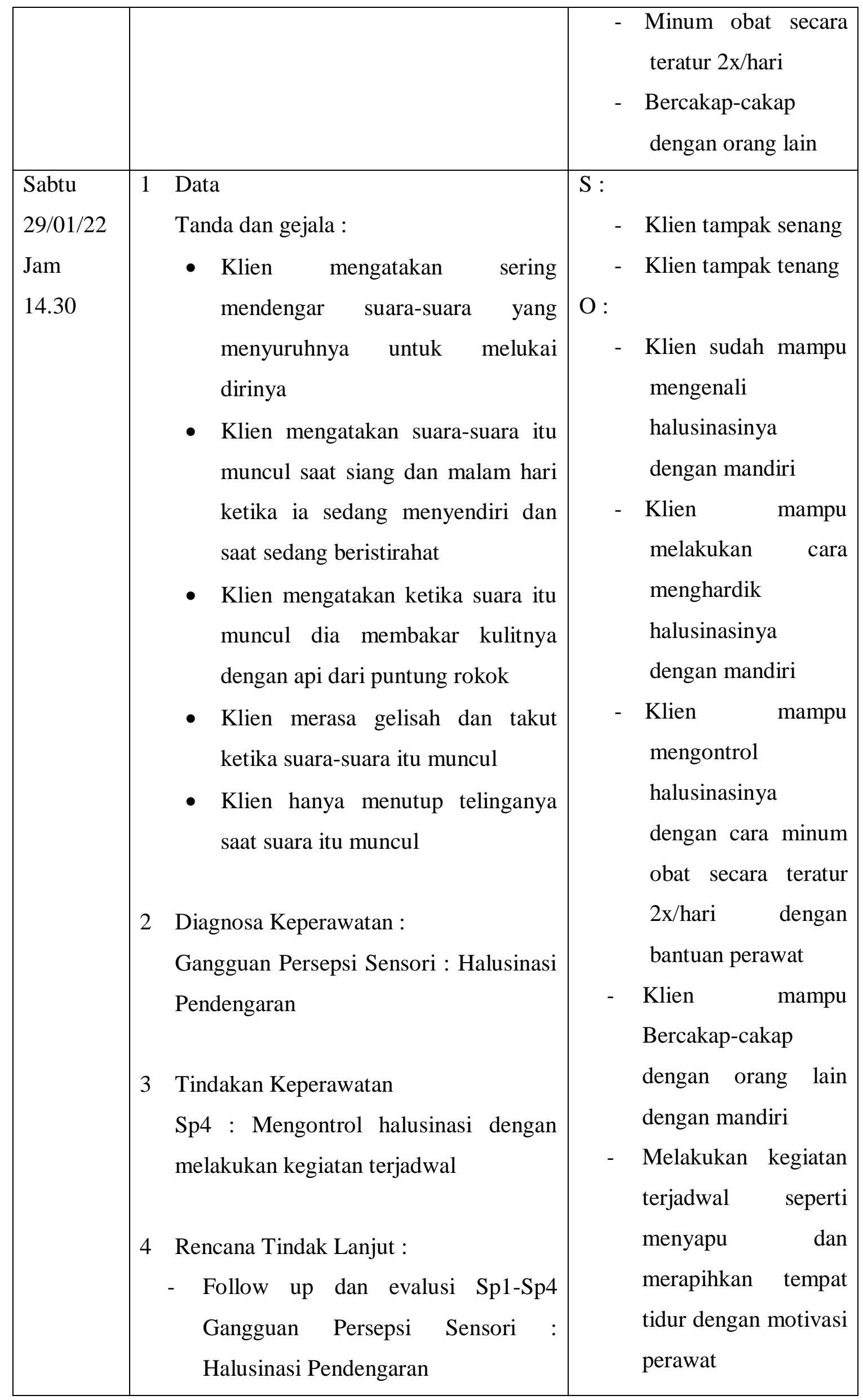




\begin{tabular}{|c|c|c|c|}
\hline & & - $\quad$ Isolasi Sosial : Menarik diri & 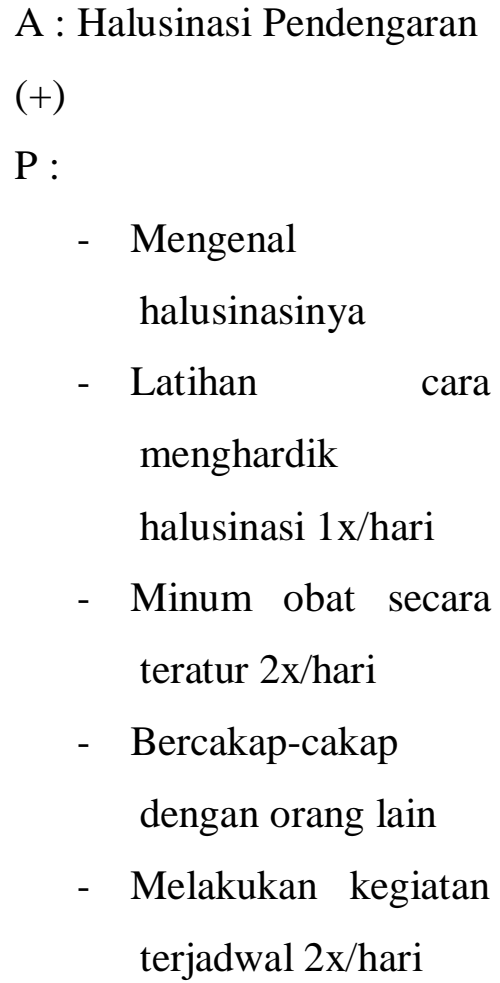 \\
\hline $\begin{array}{l}\text { Senin } \\
31 / 01 / 22 \\
\text { Jam } \\
10.00\end{array}$ & 1 & $\begin{array}{l}\text { Data } \\
\text { - Klien mengatakan dirinya lebih } \\
\text { senang untuk menyendiri } \\
\text { - Klien mengatakan tidak mampu } \\
\text { untuk berinteraksi dengan orang } \\
\text { sekitarnya karena malu akan } \\
\text { dirinya } \\
\text { Klien tampak menarik diri } \\
\text { Diagnosa Keperawatan : Isolasi Sosial : } \\
\text { Menarik Diri } \\
\text { Tindakan Keperawatan } \\
\text { Sp1 : Menjelaskan keuntungan dan } \\
\text { kerugian mempunyai teman } \\
\text { Rencana Tindak Lanjut : } \\
\text { Sp2 : Melatih klien berkenalan dengan } 2 \\
\text { orang atau lebih }\end{array}$ & 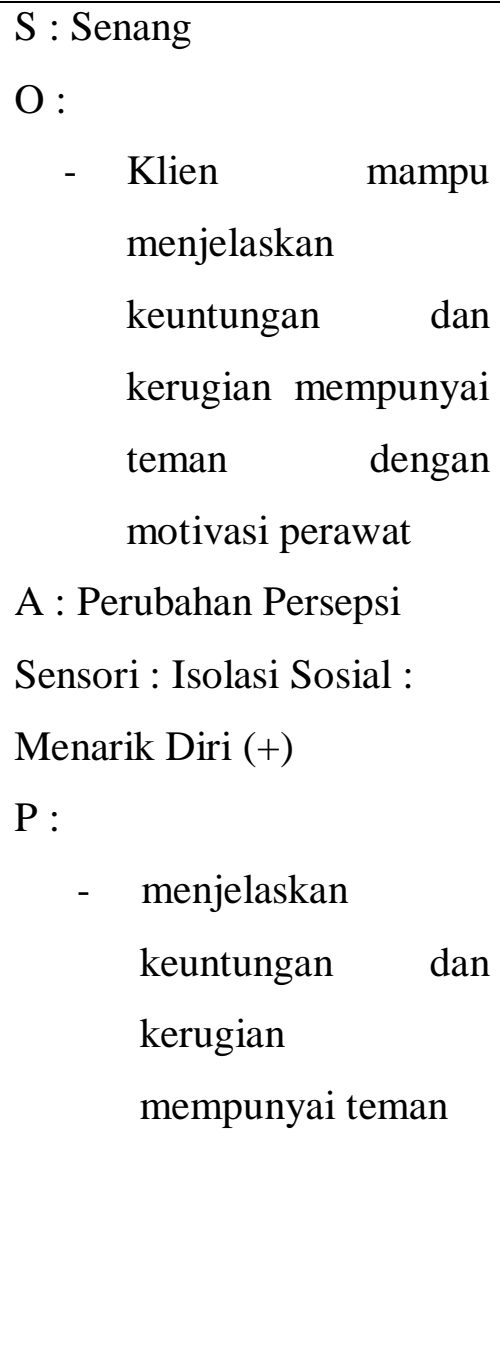 \\
\hline Rabu & 1 & Data & S : Senang \\
\hline
\end{tabular}




\begin{tabular}{|c|c|c|c|}
\hline $\begin{array}{l}02 / 02 / 22 \\
\text { Jam } \\
10.30\end{array}$ & 4 & $\begin{array}{l}\text { - Klien mengatakan dirinya lebih } \\
\text { senang untuk menyendiri } \\
\text { - Klien mengatakan tidak mampu } \\
\text { untuk berinteraksi dengan orang } \\
\text { sekitarnya karena malu akan } \\
\text { dirinya } \\
\text { - Klien tampak menarik diri } \\
\text { Diagnosa Keperawatan : Isolasi Sosial : } \\
\text { Menarik Diri } \\
\text { Tindakan Keperawatan } \\
\text { Sp2 : Melatih klien berkenalan dengan } 2 \\
\text { orang atau lebih } \\
\text { Rencana Tindak Lanjut : } \\
\text { Sp3 : Melatih klien bercakap-cakap } \\
\text { Sambil melakukan kegiatan harian }\end{array}$ & $\begin{array}{l}\text { O : } \\
\text { Klien mampu } \\
\text { menjelaskan } \\
\text { keuntungan dan } \\
\text { kerugian mempunyai } \\
\text { teman dengan } \\
\text { motivasi perawat } \\
\text { Klien dengan } \\
\text { berkenalan dengan } 2 \\
\text { orang } \\
\text { motivasi perawat } \\
\text { A : Perubahan Persepsi } \\
\text { Sensori : Isolasi Sosial : } \\
\text { Menarik Diri (+) } \\
\text { P : } \\
\text { - }\end{array}$ \\
\hline $\begin{array}{l}\text { Kamis } \\
03 / 02 / 22 \\
\text { Jam } \\
10.00\end{array}$ & 2 & $\begin{array}{l}\text { Data } \\
\text { - Klien mengatakan dirinya lebih } \\
\text { senang untuk menyendiri } \\
\text { - Klien mengatakan tidak mampu } \\
\text { untuk berinteraksi dengan orang } \\
\text { sekitarnya karena malu akan } \\
\text { dirinya } \\
\text { - Klien tampak menarik diri }\end{array}$ & $\begin{array}{ll}\text { S : Senang } & \\
\text { O : } & \\
- & \text { Klien mampu } \\
& \text { menjelaskan kembali } \\
& \text { keuntungan dan } \\
& \text { kerugian mempunyai } \\
& \text { teman } \\
& \text { mandiri } \\
& \text { Klien } \\
& \text { berkenalan dengan 2 } \\
& \text { orang } \\
& \text { mandiri dengan }\end{array}$ \\
\hline
\end{tabular}




\begin{tabular}{|c|c|c|c|}
\hline & 4 & $\begin{array}{l}\text { Tindakan Keperawatan } \\
\text { Sp3 : Melatih klien bercakap-cakap } \\
\text { Sambil melakukan kegiatan harian } \\
\text { Rencana Tindak Lanjut: } \\
\text { S4 : Melatih klien berbicara sosial : } \\
\text { meminta sesuatu, berbelanja dan } \\
\text { sebagainya }\end{array}$ & 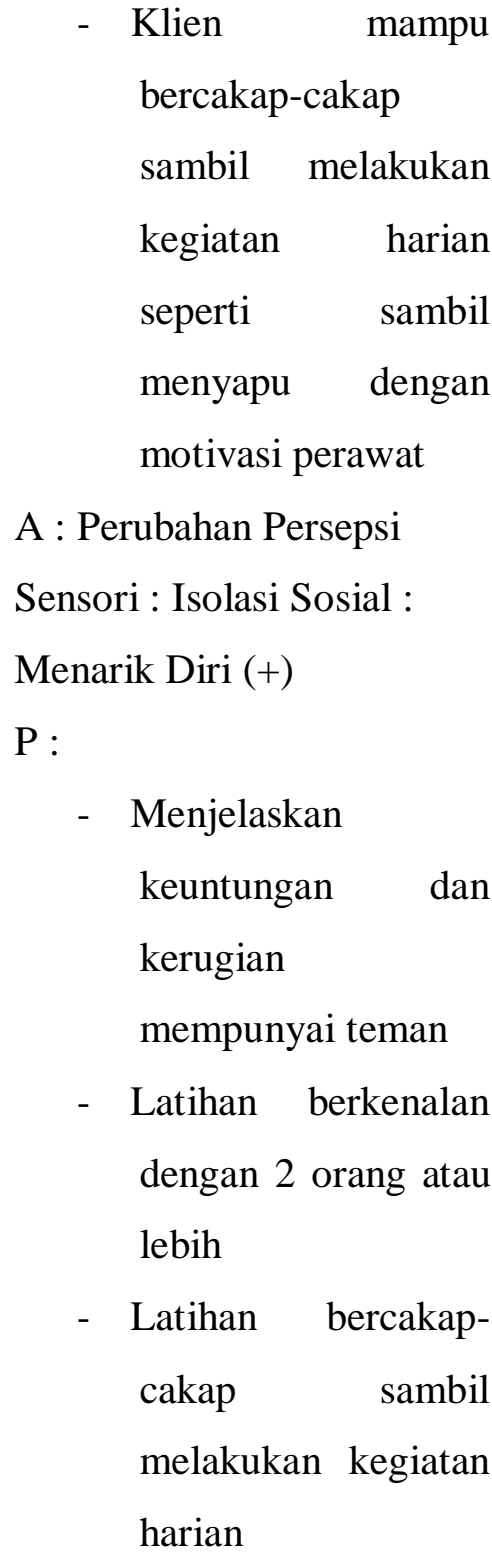 \\
\hline $\begin{array}{l}\text { Jumat } \\
04 / 02 / 22 \\
\text { Jam } \\
11.00\end{array}$ & 1 & $\begin{array}{l}\text { Data } \\
\text { - Klien mengatakan dirinya lebih } \\
\text { senang untuk menyendiri } \\
\text { - Klien mengatakan tidak mampu } \\
\text { untuk berinteraksi dengan orang } \\
\text { sekitarnya karena malu akan } \\
\text { dirinya } \\
\text { - Klien tampak menarik diri } \\
\text { Diagnosa Keperawatan } \\
\text { Isolasi Sosial ; Menarik Diri }\end{array}$ & $\begin{array}{ll}\text { S : Senang } & \\
\text { O : } & \\
\text { - } & \text { Klien mampu } \\
& \text { menjelaskan kembali } \\
& \text { keuntungan } \\
& \text { kerugian mempunyai } \\
& \text { teman } \\
& \text { mandiri } \\
& \text { Klien } \\
& \text { berkenalan dengan 2 } \\
& \text { orang } \\
& \text { mandiri }\end{array}$ \\
\hline
\end{tabular}




\begin{tabular}{|c|c|c|c|}
\hline & 4 & $\begin{array}{l}\text { Tindakan Keperawatan } \\
\text { Sp4 : Melatih klien berbicara sosial : } \\
\text { meminta sesuatu, berbelanja dan } \\
\text { sebagainya } \\
\text { Rencana Tindak Lanjut } \\
\text { - Follow up dan evaluasi Sp1-Sp4 } \\
\text { Isolasi Sosial } \\
\text { - Gangguan Konsep Diri : Harga Diri } \\
\text { Rendah }\end{array}$ & 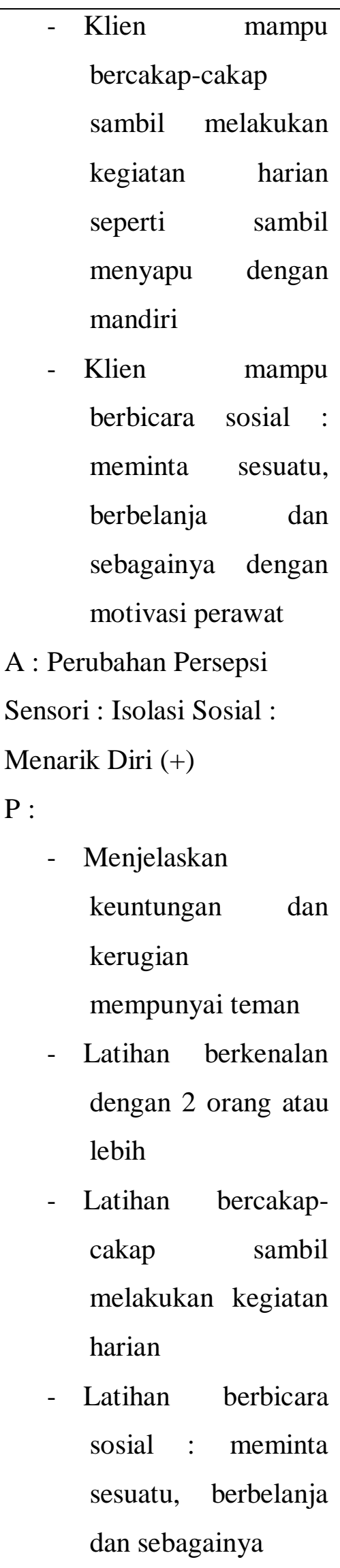 \\
\hline $\begin{array}{l}\text { Senin } \\
07 / 02 / 22\end{array}$ & 1 & $\begin{array}{l}\text { Data } \\
\text { - Klien mengatakan merasa malu dan }\end{array}$ & $\begin{array}{l}\text { S : Senang } \\
\mathrm{O}:\end{array}$ \\
\hline
\end{tabular}




\begin{tabular}{|c|c|c|c|}
\hline $\begin{array}{l}\text { Jam } \\
14.30\end{array}$ & 3 & $\begin{array}{l}\text { kurang percaya diri karena kulitnya } \\
\text { penuh bekas luka bakar } \\
\text { - Klien merasa sedih karena dirawat } \\
\text { dirumah sakit jiwa } \\
\text { - Klien mengatakan hanya } \\
\text { menyusahkan keluarga dan ingin } \\
\text { cepat sembuh } \\
\text { Diagnosa Keperawatan : } \\
\text { Gangguan Konsep Diri : Harga Diri } \\
\text { Rendah (+) } \\
\text { Tindakan Keperawatan } \\
\text { Sp1 : Mengidentifikasi kemampuan dan } \\
\text { aspek positif yang dimiliki pasien } \\
\text { Rencana Tindak Lanjut } \\
\text { Sp2 : } \\
\text { - Menilai kemampuan yang dapat } \\
\text { digunakan } \\
\text { - Menetapkan/memilih kegiatan } \\
\text { sesuai kemampuan }\end{array}$ & $\begin{array}{ll}\text { - } & \text { Klien mampu } \\
& \text { mengidentifikasi } \\
& \text { kemampuan dan } \\
& \text { aspek positif yang } \\
& \text { dimiliki klien yaitu } \\
& \text { berdoa dan } \\
& \text { bersyukur dengan } \\
& \text { motivasi perawat } \\
\text { A : Gangguan Konsep Diri : } \\
\text { Harga } \\
\text { Piri Rendah (+) } \\
\text { - Melatih klien untuk } \\
\text { memulai segala } \\
\text { sesuatu aktivitas } \\
\text { dengan berdoa dan } \\
\text { bersyukur }\end{array}$ \\
\hline $\begin{array}{l}\text { Selasa } \\
08 / 02 / 22 \\
\text { Jam } \\
14.30\end{array}$ & & $\begin{array}{l}\text { Data } \\
\text { - Klien mengatakan merasa malu dan } \\
\text { kurang percaya diri karena kulitnya } \\
\text { penuh bekas luka bakar } \\
\text { - Klien merasa sedih karena dirawat } \\
\text { dirumah sakit jiwa } \\
\text { - Klien mengatakan hanya } \\
\text { menyusahkan keluarga dan ingin } \\
\text { cepat sembuh }\end{array}$ & $\begin{array}{l}\text { S : Senang } \\
\text { O : } \\
\text { - } \\
\text { Klien mampu } \\
\text { mengidentifikasi } \\
\text { kemampuan dan } \\
\text { aspek positif yang } \\
\text { dimiliki klien seperti } \\
\text { berdoa dan } \\
\text { bersyukur secara } \\
\text { mandiri }\end{array}$ \\
\hline
\end{tabular}




\begin{tabular}{|c|c|c|c|}
\hline & 4 & $\begin{array}{l}\text { Diagnosa Keperawatan: } \\
\text { Gangguan Konsep Diri : Harga Diri } \\
\text { Rendah (+) } \\
\text { Tindakan Keperawatan } \\
\text { Sp2 : } \\
\text { - Menilai kemampuan yang dapat } \\
\quad \text { digunakan } \\
\text { - Menetapkan/memilih kegiatan } \\
\quad \text { sesuai kemampuan } \\
\text { - Melatih kegiatan sesuai } \\
\quad \text { kemampuan yang dipilih } 1 \\
\text { Rencana Tindak Lanjut } \\
\text { Sp3 : Melatih kegiatan sesuai } \\
\text { kemampuan yang dipilih } 2 \\
\text { Sp4 : Melatih kegiatan sesuai } \\
\text { kemampuan yang dipilih } 3\end{array}$ & 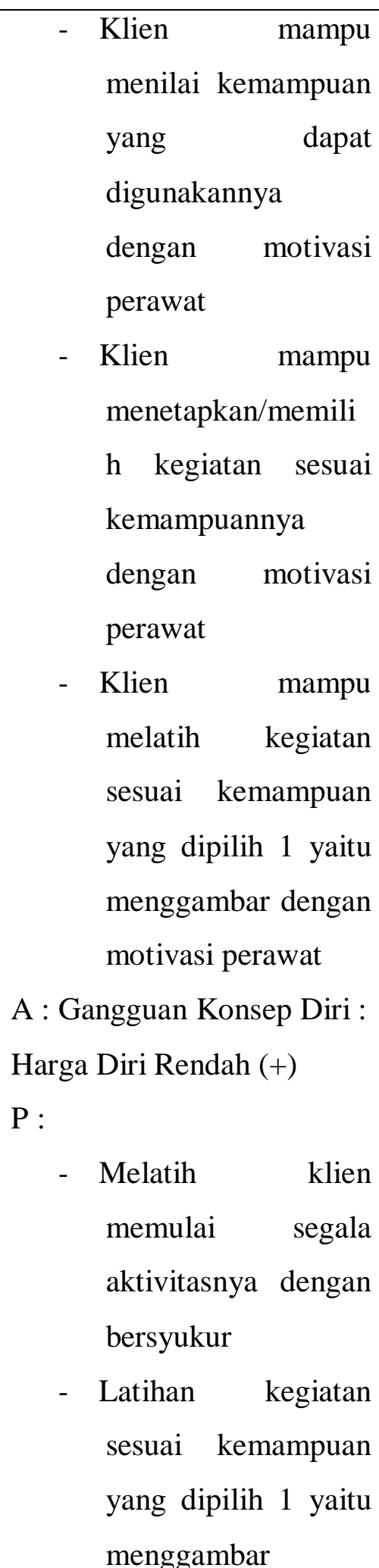 \\
\hline $\begin{array}{l}\text { Rabu } \\
09 / 02 / 22 \\
\text { Jam } \\
14.30\end{array}$ & 1 & $\begin{array}{l}\text { Data } \\
\text { - Klien mengatakan merasa malu dan } \\
\text { kurang percaya diri karena kulitnya } \\
\text { penuh bekas luka bakar } \\
\text { - Klien merasa sedih karena dirawat }\end{array}$ & $\begin{array}{l}\text { S : Senang } \\
\text { O : } \\
\text { - } \\
\text { Klien mampu } \\
\text { mengidentifikasi } \\
\quad \text { kemampuan dan }\end{array}$ \\
\hline
\end{tabular}




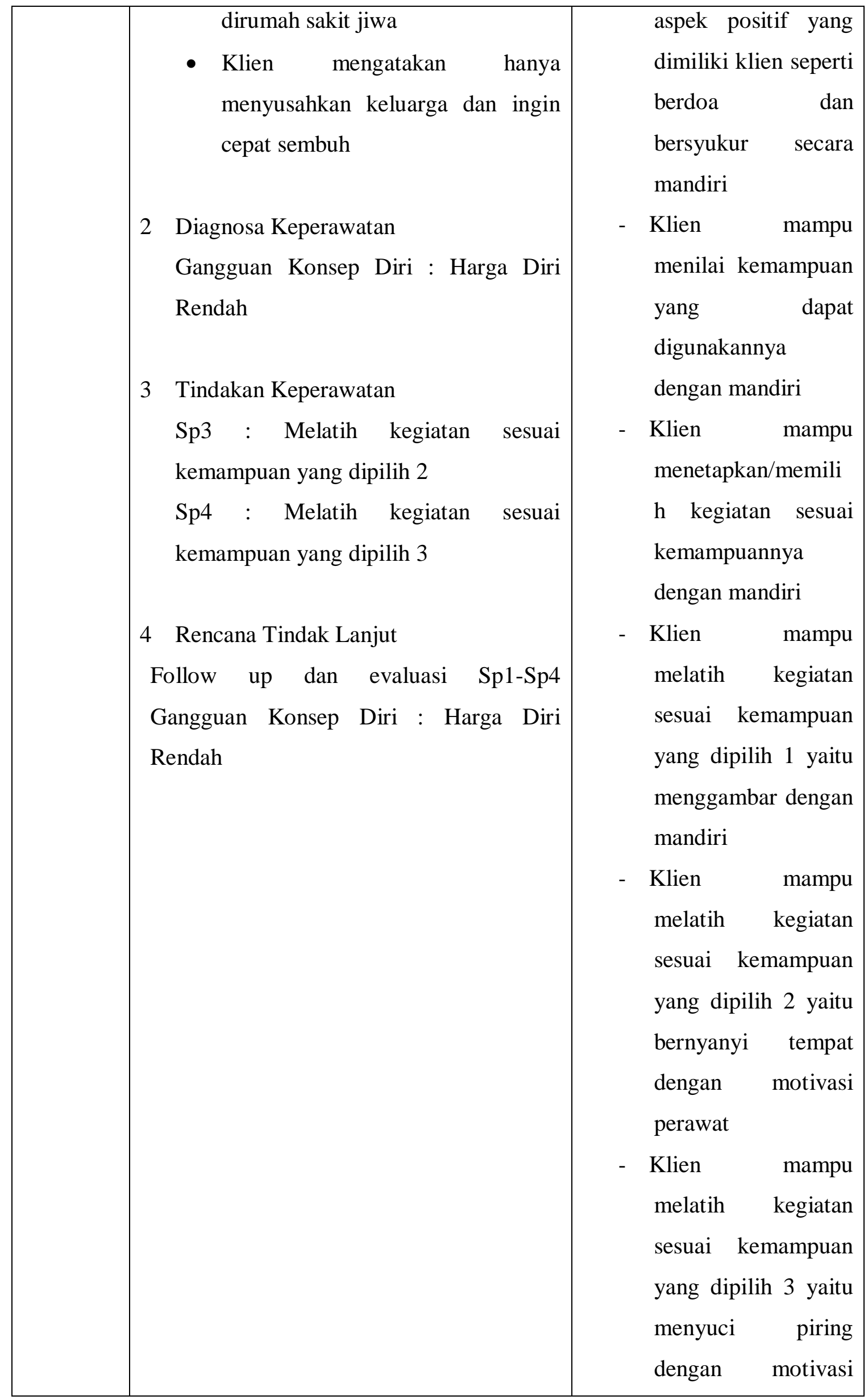




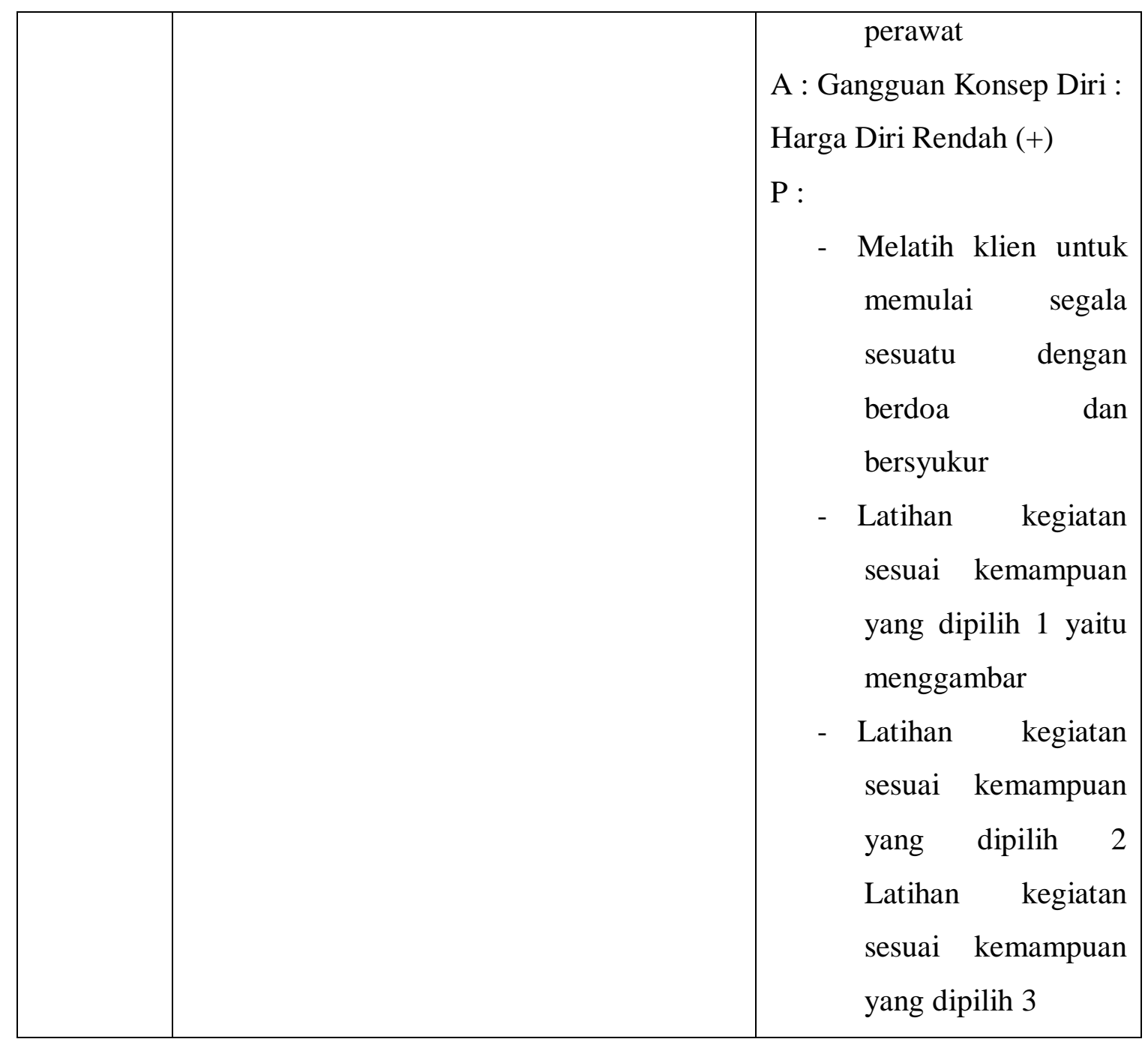




\section{BAB 4 \\ PEMBAHASAN}

Setelah penulis melaksanakan asuhan keperawatan kepada Tn.As dengan gangguan sensori persepsi: halusinasi pendengaran di ruangan sinabung, maka penulis pada $B A B$ ini akan membahas kesenjangan antara teoritis dengan tinjauan kasus. Pembahasan dimulai melalui tahapan proses keperawatan yaitu pengkajian, diagnosa keparawatan, perencanaan, pelaksanaan dan evaluasi.

\subsection{Pengkajian Keperawatan}

Pada pembahasan ini diuraikan tentang hasil pelaksanaan tindakan keperawatan dengan pemberian terapi generalis pada klien halusinasi pendengaran. Pembahasan menyangkut analisis hasil penerapan terapi generalis terhadap masalah keperawatan halusinasi pendengaran. Tindakan keperawatan didasarkan pada pengkajian dan diagnosis keperawatan yang terdiri dari tindakan generalis yang dijabarkan sebagai berikut. Tahap pengkajian pada klien halusinasi dilakukan interaksi perawat-klien melalui komunikasi terapeutik untuk mengumpulkan data dan informasi tentang status kesehatan klien. Pada tahap ini terjadi proses interaksi manusia, komunikasi, transaksi dengan peran yang ada pada perawat sebagaimana konsep tentang manusia yang bisa dipengaruhi dengan adanya proses interpersonal (Keliat, 2016)

Selama pengkajian dilakukan pengumpulan data dari beberapa sumber, yaitu dari pasien dan tenaga kesehatan di ruangan. Penulis mendapat sedikit kesulitan dalam menyimpulkan data karena keluarga pasien jarang mengunjungi pasien di rumah sakit jiwa. Maka penulis melakukan pendekatan kepada pasien melalui komunikasi terapeutik yang lebih terbuka membantu pasien untuk memecahkan perasaannya dan juga melakukan observasi kepada pasien. Adapun upaya tersebut yaitu:

a. Melakukan pendekatan dan membina hubungan saling percaya diri pada klien agar klien lebih terbuka dan lebih percaya dengan menggunakan perasaan.

b. Mengadakan pengkajian klien dengan wawancara

Dalam pengkajian ini, penulis menemukan kesenjangan karena ditemukan. Pada kasus Tn.As klien mendengar suara-suara aneh, mondar-mandir, tampak tegang, putus asa, sedih 
dan lain-lain. Gejala gejala yang muncul tersebut tidak semua mencakup dengan yang ada di teori klinis dari halusnasi (Keliat, dkk.2014). Akan tetapi terdapat faktor predisposisi maupun presipitasi yang menyebabkan kekambuhan penyakit yang dialami oleh Tn.As. Tindakan keperawatan terapi generalis yang dilakukan pada Tn.As adalah strategi pertemuan pertama sampai pertemuan empat. Strategi pertemuan pertama meliputi mengidentifikasi isi, frekuensi, jenis, dan respon klien terhadap halusinasi serta melatih cara menghardik halusinasi. Strategi pertemuan kedua yang dilakukan pada Tn.As meliputi melatih cara mengendalikan dengan bercakap-cakap kepada orang lain. Strategi pertemuan yang ketiga adalah menyusun jadwal kegiatan bersama-sama dengan klien. Strategi pertemuan keempat adalah mengajarkan dan melatih Tn. As cara minum obat yang teratur.

\subsection{Diagnosa Keperawatan}

Pada Teori Halusinasi (NANDA, 2015-2017), diagnosa keperawatan yang muncul sebanyak 3 diagnosa keperawatan yang meliputi:

1. Halusinasi

2. Isolasi social

\section{Harga diri rendah}

Sedangkan pada kasus Tn.As ditemukan diagnosa keperawatan yang muncul yang meliputi: isolasi sosial, halusinasi. Dari hal tersebut di atas dapat dilihat terjadi kesamaan antara teori dan kasus. Dimana semua diagnosa pada teori muncul pada kasus Tn.As

\subsection{Intervensi}

Intervensi yang dilakukan padamasalah keperawatan gangguan sensori persepsi: halusinasipada penelitian ini menggunakan intervensi strategi pelaksanaan (SP) dan ditambah dengan intervensi inovasi terapipenerimaan dan komitment (acceptance and commitment therapy).Strategi pelaksanaan(SP) pada intervensi masalah keperawatan gangguan sensori persepsi: halusinasi dapat diimplementasikan secara keseluruhan kepada IbuS selama 4hari, hal ini didukung oleh klien telah kooperatif dalam menerima masukan/ intervensi yang diberikan oleh penulis. Begitu juga intervensi inovasi terapipenerimaan dan komitment (acceptance and commitment therapy) dapat diaplikasikan kepada klien salama 4 hari.

Intervensi inovasi dapat dilakukan sesuai SOP yang telah dibuat edangkan untuk intervensi keperawatan pada masalah keperawatan harga diri rendah kronik hanyadapat 
diimplementasikan kepada klienselama 2 harikarena penulis harus terus menerus mengulang tindakan keperawatan intervensi SP gangguan sensori persepsi: halusinasidan intervensi inovasi terapipenerimaan dan komitment (acceptance and commitment therapy) agar klien lebih memahami dan lebih bisa mengaplikasikan intervensi tersebut apabila klien mengalami halusinasi (Avidha,2018).

\subsection{Implementasi}

Implementasi atau disebut tindakan keperawatan merupakan rangkaian perilaku atau aktivitas yang dikerjakan oleh perawat untuk mengimplementasikan intervensi keperawatan. Tindakan-tindakan pada intervensi keperawatan terdiri atas observasi, terapeutik, edukasi dan kolaborasi (Fadhillah H, 2018). Pada tahap implementasi, penulis hanya mengatasi 1 masalah keperawatan yakni: diagnosa keperawatan halusinasi. Pada diagnosa keperawatan gangguan persepsi sensori halusinasi dilakukan strategi pertemuan yaitu mengidentifikasi isi, frekuensi, waktu terjadi, perasaan, respon halusinasi. Kemudian strategi pertemuan yang dilakukan yaitu latihan mengontrol halusinasi dengan cara menghardik. Strategi pertemuan yang kedua yaitu anjurkan minum obat secara teratur, strategi pertemuan yang ke tiga yaitu latihan dengan cara bercakap-cakap pada saat aktivitas dan latihan strategi pertemuan ke empat yaitu melatih klien melakukan semua jadwal kegiatan ( Andri, 2019)

\subsection{Evaluasi}

Pada tinjauan teoritis evaluasi yang diharapkan adalah: Pasien mempercayai perawat sebagai terapis, pasien menyadari bahwa yang dialaminya tidak ada objeknya, dapat mengidentifikaasi halusinasi, dapat mengendalikan halusinasi melalui mengahrdik, latihan bercakap -cakap, melakukan aktivitas serta menggunakan obat secara teratur (Hafizudiin,2021). Pada tinjauan kasus evaluasi yang didapatkan adalah: Klien mampu mengontrol dan mengidentifikasi halusinasi, Klien mampu melakukan latihan bercakapcakap dengan orang lain, Klien mampu melaksanakan jadwal yang telah dibuat bersama, Klien mampu memahami penggunaan obat yang benar.. Selain itu, dapat dilihat dari setiap evalusi yang dilakukan pada asuhan keperawatan, dimana terjadi penurunan gejala yang dialami oleh Tn.AS dari hari kehari selama proses interaksi. 


\section{BAB 5}

\section{PENUTUP}

\subsection{Kesimpulan}

Berdasarkan uraian pada pembahasan di atas, maka penulis dapat disimpulkan bahwa:

1. Pengkajian dilakukan secara langsung pada klien dan juga dengan menjadikan status klien sebagai sumber informasi yang dapat mendukung data-data pengkajian. Selama proses pengkajian, perawat mengunakan komunikasi terapeutik serta membina hubungan saling percaya antara perawat-klien. Pada kasus Tn.As diperoleh bahwa klien mengalami gejala-gejala halusinasi seperti mendengar suara-suara, gelisah, sulit tidur, tampak tegang, mondar-mandir,tidak dapat mempertahankan kontak mata, sedih, malu, putus asa, menarik diri, mudah marah dan lain-lain. Faktor predisposisi pada Tn.AS yaitu pernah mengalami gangguan jiwa sebelumnya.

2. Diagnosa keperawatan yang muncul pada kasus Tn.As Halusinasi pendengaran, isolasi sosial, koping individu inefektif, regimen teraupetik keluarga inefektif, harga diri rendah serta keputusasaan. Tetapi pada pelaksanaannya, penulis fokus pada masalah utama yaitu halusinasi pendengaran.

3. Perencanaan dan implementasi keperawatan disesuaikan dengan strategi pertemuan pada pasien halusinasi pendengaran dan isolasi sosial.

4. Evaluasi diperoleh bahwa terjadi peningkatan kemampuan klien dalam mengendalikan halusinasi yang dialami serta dampak pada penurunan gejala halusinasi pendengaran yang dialami.

\subsection{Saran}

\section{Bagi Perawat}

Diharapkan dapat menerapkan komunikasi terapeutik dalam pelaksanaan strategi pertemuan 1-4 pada klien dengan halusinasi sehingga dapat mempercepat proses pemulihan klien.

\section{Bagi Pasien}

Laporan ini diharapkan dapat menjadi acuan dan referensi dalam memberikan asuhan keperawatan pada klien dengan halusinasi pendengaran. 


\section{DAFTAR PUSTAKA}

1. Afconneri, Y., Lim, K., \& Erwina, I. (2020). Faktor-Faktor Kekambuhan pada Klien Skizofrenia di Poliklinik Rumah Sakit Jiwa Prof. Dr. Hb Sa'anin Padang. Jurnal Endurance: Kajian Ilmiah Problema Kesehatan, 5(2), 321-330. http://doi.org/10.22216/jen.v5i2.3885

2. Andri, J., Febriawati, H., Panzilion, P., Sari, S. N., \& Utama, D. A. (2019). Implementasi keperawatan dengan pengendalian diri klien halusinasi pada pasien skizofrenia. Jurnal Kesmas Asclepius, 1(2), 146-155. https://doi.org/10.31539/jka.v1i2.922

3. Avidha, M., \& Fitriani, D. R. (2018). Analisis Praktik Klinik Keperawatan Jiwa pada Klien Gangguan Sensori Persepsi: Halusinasi dengan Intervensi Inovasi Terapi Penerimaan dan Komitmen (Acceptance And Comitment Therapy) Terhadap Tanda dan Gejala Halusinasi di Ruang Punai RSUD Atma Husada Mahakam Samarinda.https://dspace.umkt.ac.id//handle/463.2017/201

4. Direja, (2015) Buku Asuhan Keperawatan Jiwa.Yogyakarta:Nuha Medika.

5. Pardede, J. A., Keliat, B. A., \& Wardani, I. Y. (2013). Pengaruh Acceptance And Commitment Therapy Dan Pendidikan Kesehatan Kepatuhan Minum Obat Terhadap Gejala, Kemampuan Berkomitmen Pada Pengobatan Dan Kepatuhan Pasien Skizofrenia. FIK UI, Depok.

6. Pardede, J. A., \& Laia, B. (2020). Decreasing Symptoms of Risk of Violent Behavior in Schizophrenia Patients Through Group Activity Therapy. Jurnal Ilmu Keperawatan Jiwa, 3(3), 291-300.

7. Ellina, A. (2016). Pengaruh Terapi Aktifitas Kelompok (TAK) Stimulasi Persepsi Sessi 1-3 Terhadap Kemampuan Mengendalikan Halusinasi Pada Pasien Skizofrenia Hebefrenik.Strada Jurnal Ilmiah Kesehatan,1(1),56-62.Retrieved from https://sjik.org/index.php/sjik/article/view/22

8. Erviana, I., \& Hargiana, G. (2018). Aplikasi Asuhan Keperawatan Generalis Dan Psikoreligius Pada Klien Gangguan Sensori Persepsi: Halusinasi Penglihatan Dan Pendengaran. Jurnal Riset Kesehatan Nasional, 2(2), 114-123. http://dx.doi.org/10.37294/jrkn.v2i2.10

9. Fadhillah H. (2018) Standar Intervensi Keperawatan Indonesia. JakartaSelatan: DPP,PPNI http://repo.unikadelasalle.ac.id/index.php?p=show detail\&id=12909

10. Fitri, N. Y. (2019). Pengaruh Terapi Okupasi terhadap Gejala Halusinasi Pendengaran Pada Pasien Halusinasi PendengaranRawat Inap diYayasan Aulia Rahma Kemiling Bandar Lampung. Jurnal Kesehatan Panca Bhakti Lampung, 7(1),33-40. https://doi.org/10.47218/jkpbl.v7i1.58

11. Herawati, N., \& Afconneri, Y. (2020). Perawatan Diri Pasien Skizofrenia dengan Halusinasi. Jurnal Keperawatan Jiwa, 8(1), 9-20. https://doi.org/10.26714/jkj.8.1.2020.9$\underline{20}$

12. KeliatB, dkk.(2015). Proses Keperawatan Jiwa EdisiII. Jakarta: EGC. 
13. Kusumawati, Farida dan Yudi Hartono.(2018). Buku Ajar Keperawatan Jiwa.Jakarta:Salemba Medika

14. Nyumirah,S. (2016). Peningkatan kemampuan interaksi sosial (kognitif, afektif dan perilaku) melalui penerapan terapi perilaku kognitif di rsj dr amino gondoh utomo semarang. Jurnal keperawatan jiwa,1(2). https://doi.org/10.26714/jkj.1.2.2013.\%25p

15. Muhith, Abdul. (2015). Pendidikan Keperawatan Jiwa Teori Dan Aplikasi. Yogyakarta : CV Andi Offset

16. Pardede,J.A,(2020). Ekspresi Emosi keluarga yang Merawat Pasien Skizofrenia. $\begin{array}{lllll}\text { Jurnal ilmiah keperawatan Imelda, } & 6(2), & 117- & 122 .\end{array}$ https://doi.org/10.2411/jikeperawatan.v6i2.403

17. Pardede, J. A. (2019). The Effects Acceptance and Aommitment Therapy and Health Education Adherence to Symptoms, Ability to Accept and Commit to Treatment and Compliance in Hallucinations Clients Mental Hospital of Medan, North Sumatra. $J$ Psychol Psychiatry Stud, 1, 30-35

18. Pardede, J. A., Keliat, B. A., \& Yulia, I. (2015). Kepatuhan dan Komitmen Klien Skizofrenia Meningkat Setelah Diberikan Acceptance And Commitment Therapy dan Pendidikan Kesehatan Kepatuhan Minum Obat.Jurnal Keperawatan Indonesia,18(3),157-166. https://doi.org/10.7454/jki.v18i3.419

19. Pardede, J. A., Irwan, F., Hulu, E. P., Manalu, L. W., Sitanggang, R., \& Waruwu, J. F. A. P.(2021).Asuhan keperawatan Jiwa Dengan Masalah Halusinasi. $\underline{10.31219 / \text { osf.io/fdqzn }}$

20. Pardede, J. A. (2020). Family Burden Related to Coping when Treating Hallucination Patients. Jurnal Ilmu Keperawatan Jiwa, 3(4), 453-460.

21. Pardede, J. A. (2020). Family Knowledge about Hallucination Related to Drinking Medication Adherence on Schizophrenia Patient. Jurnal Penelitian Perawat Profesional, 2(4), 399-408.

22. Patricia, H., Rahayu ningrum, D. C., \& Nofia, V. R. (2019). Hubungan Beban Keluarga Dengan Kemampuan Caregiver Dalam Merawat Klien Skizofrenia.Jurnal Kesehatan Medika Saintika, 10(2), 45-52.doi: http://dx.doi.org/10.30633/jkms.v10i2.449

23. Prabowo,Eko.2014.Konsep \& Aplikasi Asuhan Keperawatan Jiwa.Yogyakarta: Nuha Medika.

24. Pratiwi, M., \& Setiawan, H. (2018). Tindakan Menghardik Untuk Mengatasi Halusinasi Pendengaran Pada Klien Skizofrenia Di Rumah Sakit Jiwa. Jurnal Kesehatan, 7(1), 7-13. http://dx.doi.org/10.46815/jkanwvol8.v7i1.76

25. Prabowo, E. (2014). Buku Ajar Keperawatan Jiwa. Yogyakarta: Nuha Medika.

26. Riskesdas (2018) Hasil Utama riskesdas 2018 Kementrian Kesehatan Badan Penelitian 
dan

https://www.kemkes.go.id/resources/download/infoterkini/hasil-riskesdas-2018.pdf

27. Sulah yuningsih, E., Pratiwi, A.,\& Teguh,S.(2016).Pengalaman Perawat Dalam Mengimplementasikan Strategi Pelaksanaan (Sp) Tindakan Keperawatan Pada Pasien Halusinasi Di Rumah Sakit Jiwa Daerah Surakarta (Doctoral dissertation,Universitas Muhammadiyah Surakarta). http://eprints.ums.ac.id/id/eprint/40858

28. Who, (2019). Schizophrenia. Retrieved from. https://www.who.int/news-room/factsheets/\%20detail/schizophrenia

29. Wahyuni, S., Yuliet, S. N., \& Elita, V. (2015). Hubungan lama hari rawat dengan kemampuan pasien dalam mengontrol halusinasi. Jurnal Ners Indonesia, 1(2), 69-76. http://dx.doi.org/10.31258/jni.1.2.69-76

30. Yosep, I. (2007). Keperawatan jiwa. Bandung: PT Refika Aditama

31. Yuanita,T.(2019).Asuhan Keperawatan Klien Skizofrenia Dengan Gangguan Persepsi Halusinasi Pendengaran DiRsjd Dr.Arif Zainudin Solo Surakarta (Doctoral dissertation,Universitas Muhammadiyah Ponorogo). http://eprints.umpo.ac.id/id/eprint/5381

32. Zelika, A. A., \& Dermawan, D. (2015). Kajian Asuhan Keperawatan Jiwa Halusinasi Pendengaran Pada Sdr. D Di Ruang Nakula RSJD Surakarta. Profesi (Profesional Islam): Media Publikasi Penelitian, 12(02). http://dx.doi.org/10.26576/profesi.87

33. Zuraida, Z. (2018). Konsep Diri Penderita Skizofrenia Setelah Rehabilitasi. Jurnal Psikologi Kognisi, 1(2), 110-124. http://dx.doi.org/10.22303/kognisi.1.2.2017.110-124 